\title{
Design and fabrication of large-sized planar oxygen transport membrane components for direct integration in oxy-combustion processes.
}

F. Schulze-Küppers ${ }^{1, *}$, F. Drago², L. Ferravante ${ }^{2}$, S. Herzog ${ }^{3}$, S. Baumann ${ }^{1}$, P. Pinacci², W.A. Meulenberg ${ }^{1}$

${ }^{1}$ Forschungszentrum Jülich GmbH, Institute of Energy and Climate Research, Materials Synthesis and Processing (IEK-1), 52425 Jülich, Germany

${ }^{2}$ RSE S.p.A., Via Rubattino 54, 20134 Milan, Italy

${ }^{3}$ Institute for Materials Applications in Mechanical Engineering (IWM), RWTH Aachen University, Augustinerbach 4, 52062 Aachen, Germany

\begin{abstract}
Membrane-based oxy-combustion is a promising technology for energy efficient combustion of carboncontaining fuels with the simultaneous opportunity to capture $\mathrm{CO}_{2}$ from the resulting exhaust gas. However, oxy-combustion conditions result in special demands on the design of the ceramic membrane components due to the high pressure and temperature applied. Therefore, we have developed a planar membrane design for 4-end operation using asymmetric membranes of $\mathrm{La}_{0.6} \mathrm{Sr}_{0.4} \mathrm{Co}_{0.2} \mathrm{Fe}_{0.8} \mathrm{O}_{3-\delta}$. FEM and CFD simulations have been performed in order to develop an internal channel structure that allows withstanding pressures of 5 bar on the feed side while achieving the desired $\mathrm{O}_{2}$ concentrations of $27 \%$ in the sweep gas, i.e. $\mathrm{CO}_{2}$, and an oxygen recovery rate from the feed gas of $86 \%$ at the same time.

Due to the symmetric design of the membrane components, they are scalable and adaptable in size. This design has been realized in a process chain from powder to the final component consisting of thin 20 $\mu \mathrm{m}$ Membrane layer, support with $38 \%$ porosity, an inner channelled architecture and a thin (3-5 $\mu \mathrm{m})$ porous activation layer. Particular emphasis was laid on scalable manufacturing processes in order to ensure transferability to industrial scale. The process chain is also applicable to other membrane materials suitable for any application of interest. Finally, the reproducible processing was successfully demonstrated by the fabrication of membrane components in lengths of $100 \mathrm{~mm}$ and widths of $70 \mathrm{~mm}$.
\end{abstract}

\footnotetext{
* Corresponding author, tel.: +49 2461 61-6712; fax: +49 2461 61-2455.
}

E-mail address: f.schulze@fz-juelich.de 


\section{Introduction}

The application of carbon capture technologies at large point sources can reduce heavily $\mathrm{CO}_{2}$ emissions $[1,2]$. The combustion of regenerative or fossil fuels with pure oxygen is an option to capture the resulting concentrated $\mathrm{CO}_{2}$ which can be reused as a raw material or stored. The lowest, inevitably

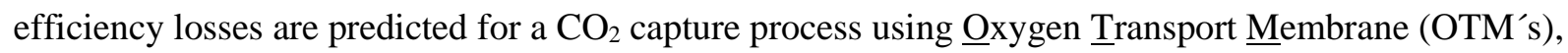
which are integrated into the heat cycle of the combustion process at temperatures $>800{ }^{\circ} \mathrm{C}$ in order to provide the oxygen with high purity [3]. For this purpose, the oxygen lean exhaust gas is recirculated and then passes the membrane as sweep-gas again. As the oxygen partial pressure on the membrane feed side is higher (i.e. compressed air), the oxygen ions are transported through the crystal lattice of the membrane. For this reason, the membrane components must also be designed to be able to maintain mechanical stability at the pressure differences and temperatures applied.

The advantage of oxygen supply via OTM is its scalability, so that even small units can be operated with consistently high efficiency. This was already demonstrated for a dead end membrane operation mode, where permeated oxygen is removed from the membrane inside by a vacuum and added to the combustion process $[4,5,6]$.Simulations show that there could be theoretical cost advantages of OTM compared to cryogenic air separation (ASU) for large scale operation such as oxy-combustion [7, 8, 9]. Nevertheless, some technological challenges still have to be overcome in order to be able to use OTM's for oxygen supply on a large scale. Due to the good scalability of the OTM technology, oxygen could be produced cost-effectively on site, even for processes with lower oxygen demand [10, 11].

The cost-efficiency of the membrane process depends significantly on the permeation rate of oxygen through the membrane. By reducing the membrane thickness, the permeation rate can be increased, whereby for membranes in $\mu \mathrm{m}$ range, a support is required to ensure mechanical stability. This concept is called asymmetric membrane and provides the highest permeation rates, reported so far [12]. A further advantage is that the trade-off between chemical stability and membrane performance can be overcome, because with this concept membranes made of stable low-flux materials, can also have high applicationrelevant permeation rates $[13,14,15]$. Asymmetric membranes are available in lab scale so far, however up-scaling was demonstrated for $\mathrm{CaTi}_{1-\mathrm{x}} \mathrm{Fe}_{\mathrm{x}} \mathrm{O}_{3-\delta}[16,17]$, for composite material $[18,19,20]$, or for $\mathrm{Ba}_{0.5} \mathrm{Sr}_{0.5} \mathrm{Co}_{0.8} \mathrm{Fe}_{0.2} \mathrm{O}_{3-\delta}[5,21,22,23]$ on tubular systems as well as for planar Systems $[4,6]$. However, a planar system, operating in a sweep gas mode is not available yet.

In order to investigate the difference in transport limitation and system-specific advantages and disadvantages, the FP7 EU-funded project GREEN-CC developed planar membrane components with a membrane area $>100 \mathrm{~cm}^{2}$ on the basis of scalable manufacturing processes suitable for mass production under oxy-combustion conditions. In this process the fuel (e.g. in fossil-fired power plants or cement plants) is combusted with pure oxygen instead of air. The exhaust gas is recirculated and passed through the membrane as sweep gas, which in turn must be enriched with $\mathrm{O}_{2}$, up to an $\mathrm{O}_{2}$ concentration of $>23 \%$. At the same time, more than $80 \%$ of the oxygen must be withdrawn from the 
hot feed gas (i.e. compressed air), in order to minimize heat losses. The application-oriented oxycombustion process conditions of pressure differences up to several bar at temperatures $>800{ }^{\circ} \mathrm{C}$ place particular challenges regarding the design. In this work the design, based on Finite Element modelling (FEM) and Computational Fluid Dynamics analysis (CFD) is developed. Based on these simulation results, the membrane component was manufactured from $\mathrm{La}_{0.6} \mathrm{Sr}_{0.4} \mathrm{Co}_{0.2} \mathrm{Fe}_{0.8} \mathrm{O}_{3-\delta}$ (LSCF) which acts as a model material, as it is available with different microstructures, grain sizes and particle size distributions.

\section{Experimental}

\section{Computational simulation methods}

Module-concept

The membrane module configuration is illustrated in Figure 1. It consists of three integrated membrane components $10 \times 10 \mathrm{~cm}^{2}$ in size, each located between two metallic functional plates and sealed by ceramic-metal joining. In case of fracture of one membrane a separation plate, placed between every membrane stack, prevents the damage of other membranes. To facilitate the understanding, sealants between the metallic plates are not presented. The gas supply occurs with vertical inlets and outlets, and feed and sweep gas are fed in countercurrent mode. The sweep gas is fed in the flow channels of the membrane element at atmospheric pressure, while the feed gas is fed on the membrane layer at high pressure.

Normally, tubes are used for homogeneous pressure distribution. In order to ensure homogeneous load distribution in the planar system bar shaped stability elements from porous material were inserted between the asymmetric membranes, which ensure sufficient mechanical stability of the components (c.f. Figure 1). 

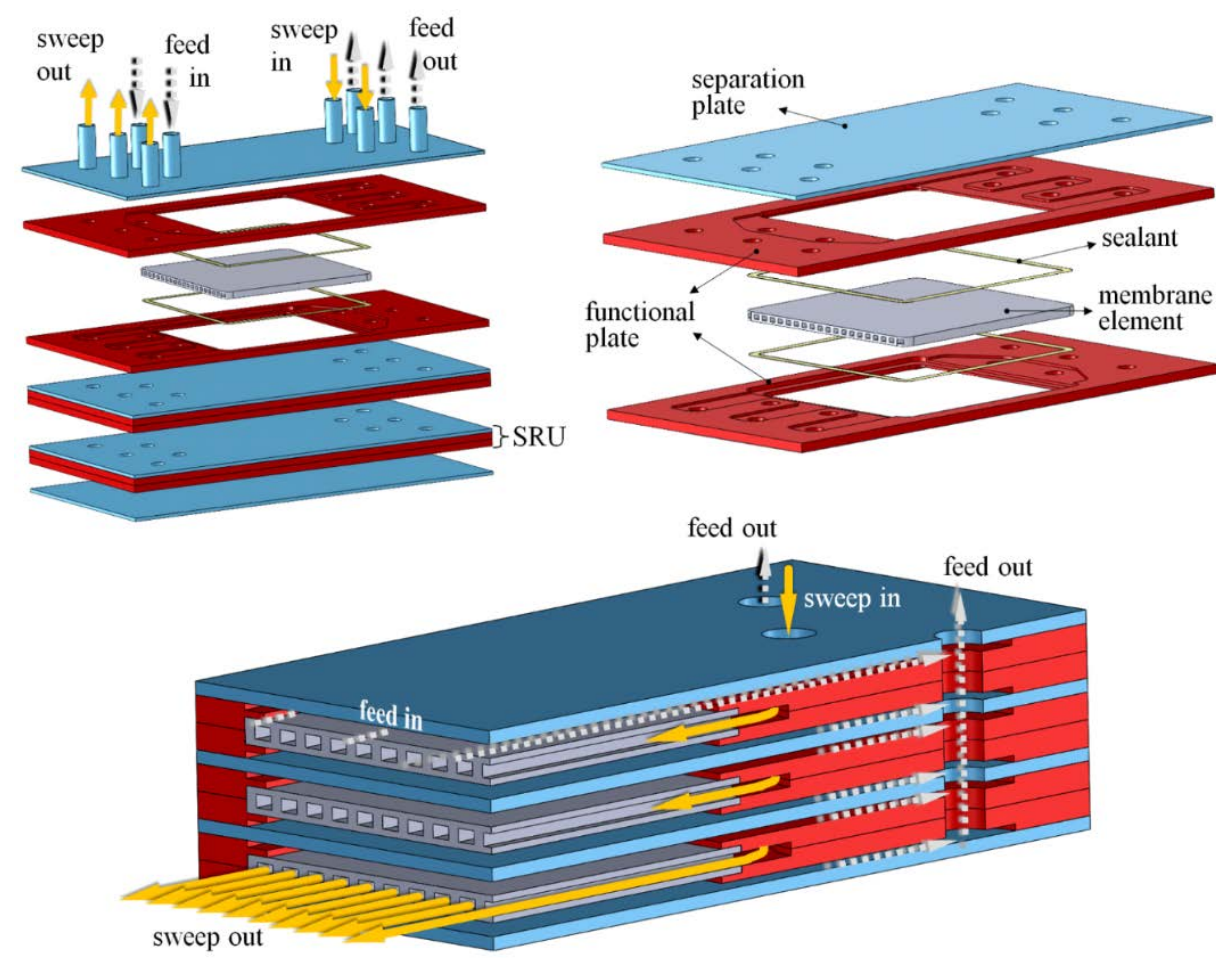

Figure 1: Design idea of a planar membrane module stack operating in 4-end mode (top left), single repeating unit SRU (top right) and quarter section with illustrated flow of feed and sweep gas.

\section{Finite Element analysis}

To investigate the mechanical stresses in the membrane components static simulations have been conducted by Abaqus. The fracture probability [24] was investigated for symmetric membrane of 100 x $100 \mathrm{~mm}^{2}$ size made of LSCF showing a linear elastic behavior. Varied numbers and dimensions of stability elements are used in a parametric study to identify configurations with fracture probabilities below $10^{-6}$. In a first approach a two dimensional model in which the asymmetric membrane is joined to a metallic frame, see Figure 2, was arranged in Abaqus. Designed as one part (solid shell elements) with different material sections, the asymmetric LSCF membrane with the dense membrane layer on top (green) is fixed to equidistant distributed stability elements (blue), braze material (red) and the metallic housing (yellow). The part is considered as stress free at $850{ }^{\circ} \mathrm{C}$ and loading by the feed pressure is applied as one step. All design parameter and parameter ranges are given in Table 1.

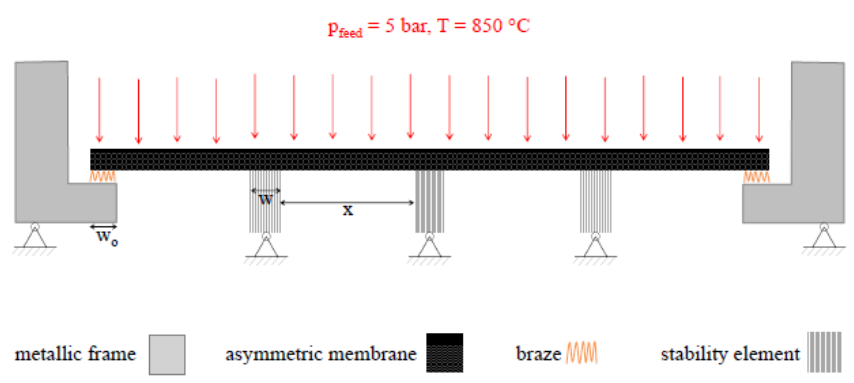

Figure 2: Overview of the 2D FE-model. 
Table 1 Investigated parameter and parameter ranges of the FEM study.

\begin{tabular}{lcc}
\hline symbol & parameter name & parameter range \\
\hline$p_{\text {feed }}$ & feed pressure & $5 \mathrm{bar}-25 \mathrm{bar}$ \\
\hline$p_{\text {sweep }}$ & sweep pressure & $1 \mathrm{bar}$ \\
\hline$T$ & temperature & $850{ }^{\circ} \mathrm{C}$ \\
\hline$w$ & stability element width & $2 \mathrm{~mm}-5 \mathrm{~mm}$ \\
\hline$x$ & stability element distance & $3.6 \mathrm{~mm}-90 \mathrm{~mm}$ \\
\hline$n$ & number of stability elements & $0-10$ \\
\hline$t_{\text {sup }}$ & thickness porous support & $300 \mu \mathrm{m}-3000 \mu \mathrm{m}$ \\
\hline$t_{\text {mem }}$ & thickness dense membrane & $30 \mu \mathrm{m}$ \\
\hline
\end{tabular}

The material properties of the different part sections is specified in Table 2. Porous and dense LSCF were modelled with linear elastic material behavior. An Estimation of Young's Modulus for porous LSCF due to increased porosity was derived from [27]. Normalized fracture strength and Weibull modulus for LSCF at $850{ }^{\circ} \mathrm{C}$ were not available and thus derived from the similar OTM material BSCF [25]. The braze (silver) and metallic housing were modeled with elastic-plastic material behavior. Exhibiting similar thermal expansion coefficients to LSCF, the nickel based alloy 602CA was chosen for the metallic frame. Data for the Poisson ratio were derived from a similar nickel alloy [30].

Table 2 Basic material properties of finite element analysis.

\begin{tabular}{|c|c|c|c|c|c|}
\hline & $\begin{array}{c}\text { Young's } \\
\text { Modulus E } \\
\text { [MPa] }\end{array}$ & $\begin{array}{c}\text { Poisson ratio } \\
v \\
{[-]}\end{array}$ & $\begin{array}{c}\text { Yield } \\
\text { strength } \sigma_{\mathbf{Y}} \\
\text { [MPa] }\end{array}$ & $\begin{array}{c}\text { normalized } \\
\text { fracture strength } \\
\sigma_{0, \mathrm{v}}[\mathrm{MPa}]\end{array}$ & $\begin{array}{c}\text { Weibull } \\
\text { modulus m } \\
{[-]}\end{array}$ \\
\hline LSCF dense & $70000^{[25]}$ & 0.25 & - & $128^{[26]}$ & $7.4^{[26]}$ \\
\hline LSCF porous & $50000^{[27]}$ & 0.25 & - & $128^{[26]}$ & $7.4^{[26]}$ \\
\hline Braze & $42000^{[28]}$ & $0.389^{[28]}$ & $17.4^{[28]}$ & - & - \\
\hline Alloy 602CA & $145500^{[29]}$ & $0.362^{[30]}$ & $193^{[29]}$ & - & - \\
\hline
\end{tabular}

The FEM analysis offers a principal stress $\sigma_{I, \max }$ in the ceramic and an effective loaded volume of the asymmetric membrane $V^{\prime}{ }_{a m}$. Due to the simplified model in only two dimensions (third dimension is automatically set as $1 \mathrm{~mm}$ ) the output value of the simulations has to be multiplied by the length dimension $100 \mathrm{~mm}$ of the asymmetric membrane (2D stress distribution is assumed to be constant about the entire membrane length) to gain the effective loaded volume of the asymmetric membrane $V_{a m}$. A characteristic fracture probability of the asymmetric membrane $\sigma_{0, a m}$ can be calculated using the size effect equation [24]. 


$$
\sigma_{0, \text { comp }}=\sigma_{0, \text { sample }} \cdot\left(\frac{V_{\text {sample }}}{V_{\text {comp }}}\right)^{1 / m}
$$

with $\sigma_{0, \text { sample }}$ the characteristic fracture probability of a sample fracture test, $V_{\text {sample }}$ the effective loaded tensile volume of the sample and $m$ the Weibull modulus of the sample fracture test. The application of this equation assumes that the Weibull modulus and thus the defect distribution of sample and component are comparable. Equation 2 gives the relationship between the first maximum principal stress of the simulation $\sigma_{I, \text { max }}$ and the fracture probability of the component $P_{f, \text { comp }}$

$$
P_{f, \text { comp }}=1-\exp \left[-\left(\frac{\sigma_{I, \max }}{\sigma_{0, \text { comp }}}\right)^{m}\right]
$$

Equation 2

Since stability elements hinder the flow of feed gas and thus the oxygen permeation, the membrane area covered by stability elements should be as low as possible but still guarantee a fracture probability below $0.01 \%$. In this context the introduction of the effective membrane area $A_{\text {eff }}$ simplifies the evaluation of simulation results:

$$
A_{\text {eff }}=\frac{A_{\text {total }}-\left(w \cdot n+4 \cdot w_{o}\right) \cdot 100 m m}{A_{\text {total }}}
$$

Equation 3

with $A_{\text {total }}$ the total membrane area of $10.000 \mathrm{~mm}^{2}$ and $w_{o}$ the width of the overlap between metallic housing and membrane component. $\mathrm{w}_{\mathrm{o}}$ is fixed to $5 \mathrm{~mm}$ and reflects a realistic value to guarantee gas tightness of the sealing area.

\section{Computational Fluid Dynamics analysis-model description}

The simulations were carried out by using a 3-D finite element method based on the commercial software Comsol Multiphysics ${ }^{\circledR}$ coupled with a SolidWorks 3D CAD module.

The model considers a detailed chemical composition of the feed and sweep gases, the diffusion of oxygen both in the feed and in the permeate regions and coupling of feed and sweep side volumes with a membrane permeation law (by using a series of user-defined functions in COMSOL $®$ software) and simultaneous solving of CFD and diffusion in calculations. The simulations were performed using steady-turbulent flow conditions at high temperature $\left(850^{\circ} \mathrm{C}\right)$ for solving fluid flow distribution and convection/diffusion equations to solve oxygen transport in both feed and sweep compartment (Maxwell-Stefan diffusion model for feed volumes and Fick's law for sweep/permeate volumes). The discretization of the governing equations was performed using a segregated solver in which each governing equation is solved separately [31, 32]. 
Specific boundary conditions have been defined, i.e. the membrane surface at the feed side and at the permeate side have been set as a mass sink and as mass source, respectively. The fully coupled model considers the local variations of flux and $\mathrm{O}_{2}$ concentration/partial pressure both in sweep and in feed, thus approaching real gases behavior. The velocity fields, the temperatures and the pressure levels are determined by solving the momentum, heat and mass transfer equations. They, in turn, influence oxygen permeation through the membrane. Further, oxygen permeation significantly influences the velocity

The following semi-empirical law was used for $\mathrm{O}_{2}$ permeation through the asymmetric LSCF membrane [33]:

$$
j_{O_{2}}=\frac{k_{0}}{L} e^{\left(-E_{a} / R T\right)} \ln \left(\frac{p_{O_{2}}^{\prime}}{p_{O_{2}}^{\prime \prime}}\right)
$$

with oxygen permeation rate $j_{O_{2}}$, the permeation constant $\mathrm{k}_{0}=0.218 \mathrm{~mol} \mathrm{~m}^{-1} \mathrm{~s}^{-1}$, apparent activation energy $E_{a}=1.24 \mathrm{~kJ} \mathrm{~mol}^{-1}$, membrane layer thickness $\mathrm{L}=30 \mu \mathrm{m}$, the , temperature $\mathrm{T}$, gas constant $\mathrm{R}$, oxygen partial pressure $p_{\mathrm{O}_{2}}^{\prime}$ and $p_{\mathrm{O}_{2}}^{\prime \prime}$ at the feed and permeate side, respectively. The constants $\mathrm{k}_{0}$ and the apparent activation energy $E_{a}$ were obtained from oxygen permeation measurements on disc shaped asymmetric membranes with comparable microstructure under the relevant gas conditions from [33, 34].

Fixed binary gas composition (feed: $79 \% \mathrm{~N}_{2}, 21 \% \mathrm{O}_{2}$; sweep: $97 \% \mathrm{CO}_{2}, 3 \% \mathrm{O}_{2}$ ), sweep gas pressure (1 bar), and constant temperature $\left(850^{\circ} \mathrm{C}\right.$ ) are used for all the simulations, while feed gas flow rate, sweep gas flow rate and feed pressure are varied in a proper range Output of simulations are: the spatial distributions of oxygen, the diffusive oxygen flux, the depletion of oxygen and pressure drops in the feed flow, the oxygen and partial pressure increase in the permeate.

\section{Material and microstructure characterization methods}

LSCF60 powder, synthesized by solid-state reaction (SSR), for tape casting was purchased as R\&D batch by Solvay Flour GmbH, Germany. Additionally a $\mathrm{La}_{0.58} \mathrm{Sr}_{0.4} \mathrm{Co}_{0.2} \mathrm{Fe}_{0.8} \mathrm{O}_{3-\delta}$ (LSCF58) powder for garnishing was fabricated in house by spray drying. In order to establish reliable processes all powders were thoroughly quality controlled. Powder morphology was investigated by determination of the specific surface area using nitrogen adsorption method (Areamat, Jung Instruments, Germany), the particle size distribution (PSD) by laser diffractometriy using a Horiba LA-950 V2 (Retsch Technology, Germany) and powder shape by scanning electron microscopy (SEM) using a Carl Zeiss Ultra 55. Phase content of the powders was investigated by x-ray diffraction (XRD) using a Bruker D4 Endeavour using $\mathrm{Cu}$ K $\alpha$ radiation (Alpha average: $1.5413 \AA$ ). Chemical composition was tracked by inductively coupled plasma with optical emission spectroscopy (ICP-OES) with a precision of 1 - $3 \%$ for major elements. 
The LSCF60 powders show a $\mathrm{d}_{50}$ of $2.2 \mu \mathrm{m}$ and a specific surface area $\mathrm{A}_{\text {spec }}$ of $0.9 \mathrm{~m}^{2}$. The Spray dried LSCF58 powder was additionally calcined at $900^{\circ} \mathrm{C}$ for $5 \mathrm{~h}$ to form the rhombohedral perovskite structure. The sprayed particles are partly sintered, round shaped core-shell structures with a surface area of approx. $3 \mathrm{~m}^{2} / \mathrm{g}$. The powder was subsequently processed by ball milling for $24 \mathrm{~h}$ in ethanol.

Microstructure parameters, such as porosity and membrane layer thickness, of sintered bodies were analysed on polished cross sections by SEM (Zeiss Ultra 55 and FEI Phenom) and quantitative image analysis. Values were determined from 10 pictures (cross section) across the whole membrane length using the commercial software analySIS.

Samples for investigation of the sintering behavior were uniaxial dry pressed with a diameter of $8 \mathrm{~mm}$. To investigate the sintering behavior of the green tapes, single layers of membrane or support tapes were made by tape casting. A first layer was cast with a blade gap of $5 \mathrm{~mm}$, a second layer of the same slurry was cast with a blade gap of $8 \mathrm{~mm}$ on top of the first after drying. Samples for dilatometric investigation of sintering behavior were cut out of the green tape. Investigation of the sintering behavior was performed with a heating and cooling rate of $5 \mathrm{~K} / \mathrm{min}$ up to $1200^{\circ} \mathrm{C}$ and $1300^{\circ} \mathrm{C}$ respectively, in a Netzsch dilatometer 402E using air as purging gas.

The burn out of the organic components from the tape cast specimen was tracked by weight changes using thermogravimetric measurements (TG). The released energy was tracked using Differential thermal analysis (DTA). The DTA/TG was performed under ambient flowing air in a temperature range from room temperature up to $1000^{\circ} \mathrm{C}$ using a Netzsch STA 449 F1 Jupiter. The measurement was performed on membrane tape, which contains binder and plasticizers as organic components only, and support tape, which contains additionally $30 \mathrm{wt} \%$ corn starch.

Gas tightness of asymmetric membranes is monitored by a He-leak test using a mass spectrometer, Pfeiffer Vacuum GmbH, HLT260.

\section{Manufacturing technologies}

Asymmetric membrane and interlayer are manufactured by tape casting. Tape casting slurries for membrane layers were prepared without pore forming agent, support and interlayer slurries contained corn starch (Cargill C-Gel, Germany), with a particle size of 2-50 $\mu \mathrm{m}$ (determined by laser diffractometry), as pore forming agent, in order to create a percolating pore network after burn out. The slurry was prepared by dispersion of the LSCF60 SSR powder (Solvay Flour GmbH, Germany) and pore forming agent in an Ethanol and Methyl Ethyl Ketone (MEK) mixture using Nuosperse FX9086 (Elementis Specialties, Inc.) as dispersant. For mechanical stability Polyvinyl Butyral (Butvar ${ }^{\circledR}$ PVB B-98, Solutia Inc.) issued as binder and Solusolve 2075 (Solutia Inc.) as plasticizer I and PEG400 (Merck) as plasticizer II is used for flexibility of the green tapes. Slurry preparation was performed in a 
two-step procedure, where solvent, dispersant, ceramic powder and pore forming agent (for substrate only) were mixed in a first step to form a suspension. In the second step, binder and plasticizers I and II were added. After each step, the slurry was homogenized by mixing. To dissolve the binder completely and to enable air to bubble up, the slurry rested 48 hours.

Sequential tape casting was used to prepare the asymmetric membranes, as described in [35, 34]. First, the dense membrane layer was cast on a polymer foil, using a $50 \mu \mathrm{m}$ doctor blade gap and the slurry without pore forming agent. Casting the membrane layer first results in a defect free layer of homogenous thickness. After drying, the support layer was cast on top of the membrane layer with a doctor blade gap of $1.9 \mathrm{~mm}$ using a slurry containing corn starch as pore forming agent. After drying, the samples were cut out of the green tape using a scalpel. Tapes for manufacturing the porous interlayers were manufactured by tape casting with a blade gap of $2.7 \mathrm{~mm}$ also using the slurry containing pore former in order to enable gas exchange between the support structure and asymmetric membrane.

Cutting of interlayers was performed by punching out the flow channels from the $1300 \mu \mathrm{m}$ thick dried interlayer green foils on a hydraulic press.

A "half cell" is half of a component unit. Asymmetric membrane and interlayer are laminated with help of a warm press (Paul-Otto Weber, PWV 50EHS, Germany). Calibers were placed on the press bench next to the sample, in order to fix the travel distance of the press and to avoid an exceeding deformation of the membrane laminate. The thickness of the calibers is $1-3 \%$ lower than the overall thickness of the multi-layered sample.

These half cells were sintered in air at $1300^{\circ} \mathrm{C}$ for $5 \mathrm{~h}$. After sintering, two half cells were combined to a component by means of garnishing using a $\mathrm{La}_{0.58} \mathrm{Sr}_{0.4} \mathrm{Co}_{0.2} \mathrm{Fe}_{0.8} \mathrm{O}_{3-\delta}$ (LSCF58) paste, consisting from $50 \mathrm{wt} \%$ spray dried LSCF58 powder, $48 \mathrm{wt} \%$ Terpineol (Alfa Aesar) and $2 \mathrm{wt} \%$ Ethylcellulose (Acros Organics) Subsequently, the component was ground to the final dimensions of $7 \mathrm{x} 10 \mathrm{~cm}^{2}$. The garnishing paste was used after reworking to apply a porous activation layer to the outside of the component by means of roll coating. The layers were calcined at $1100^{\circ} \mathrm{C}$ for 5 hours. 


\section{Results and Discussion}

\section{Computational simulation on component design}

Design requirements

The planar membrane components developed in this project are based on the idea of allowing a sweep gas to pass through between two thin-layer membranes. These thin dense layers are carried by a porous support which ensures mechanical stability to a certain extent. The membrane component is pressurized with 5 bar at $850{ }^{\circ} \mathrm{C}$ on the outer feed side. On the inner sweep gas side, on the other hand, there is a slight pressure above ambient pressure. This pressure difference driven compressive stresses makes additional design engineering measures necessary to take up the load inside the membrane component. The targets in terms of $\mathrm{O}_{2}$ concentration in the sweep gas is an $\mathrm{O}_{2}$ concentration $>23 \%$ and $\mathrm{O}_{2}$ recovery at the feed side of $>80 \%$.

\section{Finite Element analysis}

A screening of possible support thicknesses was conducted in the range of 300 to $3000 \mu \mathrm{m}$ with a dense membrane layer thickness of $30 \mu \mathrm{m}$ and an asymmetric membrane width of $100 \mathrm{~mm}$. Stability elements were not considered yet. The maximum principal stress in the asymmetric LSCF membrane decreases exponentially when increasing support thickness from $960 \mathrm{MPa}$ at $300 \mu \mathrm{m}$ to a minimum level of 230 MPa at $1000 \mu \mathrm{m}$. The highest stresses arise in the dense membrane layer in an intense bended area near the metallic bearing where the membrane has to be brazed to the metal frame as depicted in the stress distribution, given in Figure 3 (top). With increasing support thickness and thus with increasing stiffness of the ceramic LSCF component, the bending close to the bearing is reduced and shifted to a strong plastic deformation in the metallic bearing and increasing stresses in the middle of the porous ceramic support as shown in Figure 3 (bottom). An estimation of fracture probabilities for the LSCF components results in $100 \%$ failure for all analyzed thicknesses. The variation of the thickness of the porous support did not result in sufficient stress reduction for the membrane component. Based on the manufacturing options of the asymmetric membrane, a carrier thickness of $670 \mu \mathrm{m}$ was assumed and additional stability elements on the sweep side were added for the calculation. 

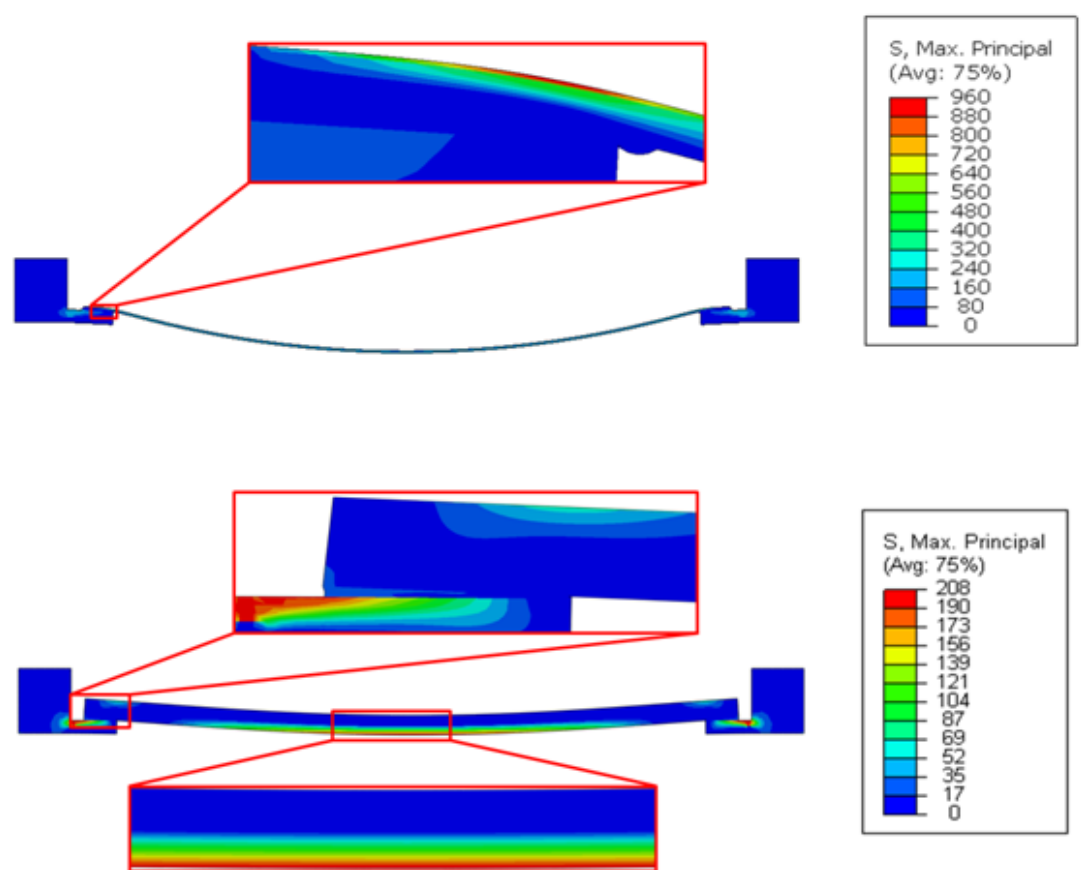

Figure 3: Maximum principle stress $\sigma_{I, \text { max }}$ without stability elements and (top) a thin porous support ( $p_{f e e d}=5$ bar, $\left.t_{\text {sup }}=300 \mu \mathrm{m}, t_{\text {mem }}=30 \mu \mathrm{m}\right)$, (bottom) a thick porous support $t_{\text {sup }}=3000 \mu \mathrm{m} . p_{\text {feed }}=5$ bar and $t_{\text {mem }}=30 \mu \mathrm{m}$.

As expected, introducing stability elements on the sweep side reduces the stress level more significantly than thickness changes of the porous LSCF support. The results are summarized in Figure 4 (left). With increasing number of stability elements (equidistant distributed on the length of $100 \mathrm{~mm}$ ), the fracture probability can be decreased from $100 \%$ to below $0.01 \%$. An additional simulation shows the serious effect of feed pressure on the fracture probability when using five stability elements. The maximum principle stress increases linearly until $15 \mathrm{MPa} / \mathrm{bar}$ thus the fracture probability again reaches $100 \%$ at only 10 bar. In order to keep the probability of failure low, the feed gas pressure should be therefore 5 bar.
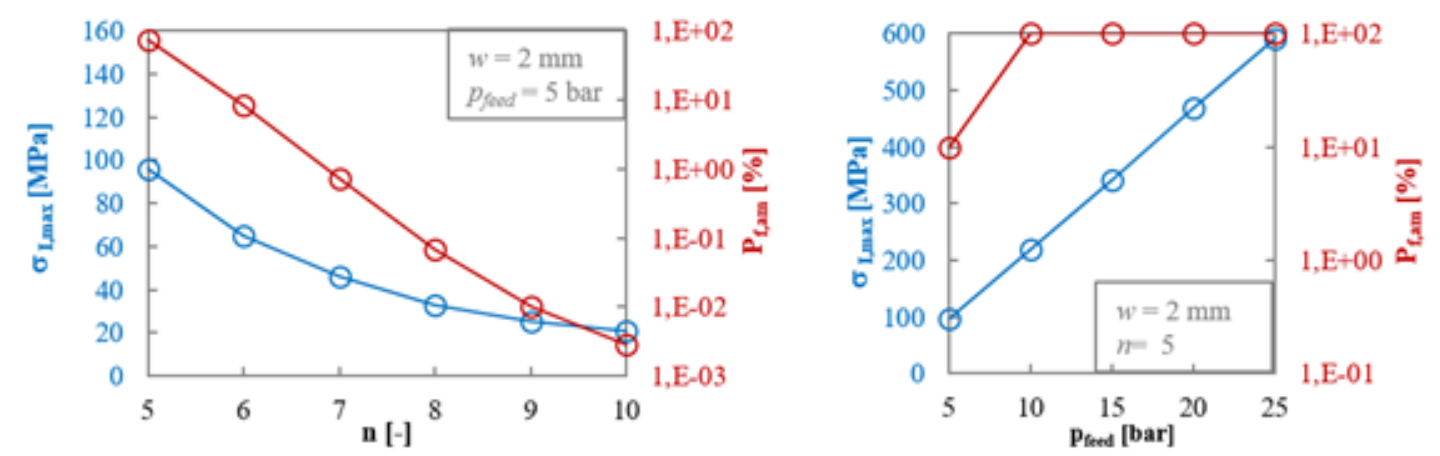

Figure 4: Maximum principal stress in asymmetric LSCF membrane with different numbers of stability elements $n$ over 100 length (left) and at different feed pressure $p_{\text {feed }}$ (right).

Due to the overlapping of the asymmetric membrane surface by the porous stability elements, the effective area $A_{\text {eff }}$ for oxygen supply is lowered. To maintain as much effective membrane area as 
possible, while preserving mechanical stability, the stability element widths $w$ was decreased from $5 \mathrm{~mm}$ to $1 \mathrm{~mm}$, see Figure 5. Note, that the number of stability elements changed to maintain a similar distance between stability elements $x$ in the range $10.3-11.1 \mathrm{~mm}$. The bending of the asymmetric membrane at positions without stability elements leads to local tensile stress fields. With decreasing width $w$ of the stability elements these stress fields narrow and finally superpose at $w=1 \mathrm{~mm}$, the stress level $\sigma_{I, \max }$ is slightly increased while the effective loaded Volume $V_{a m}$ is decreased. In general the fracture probability is not much affected by the changed stability element width.
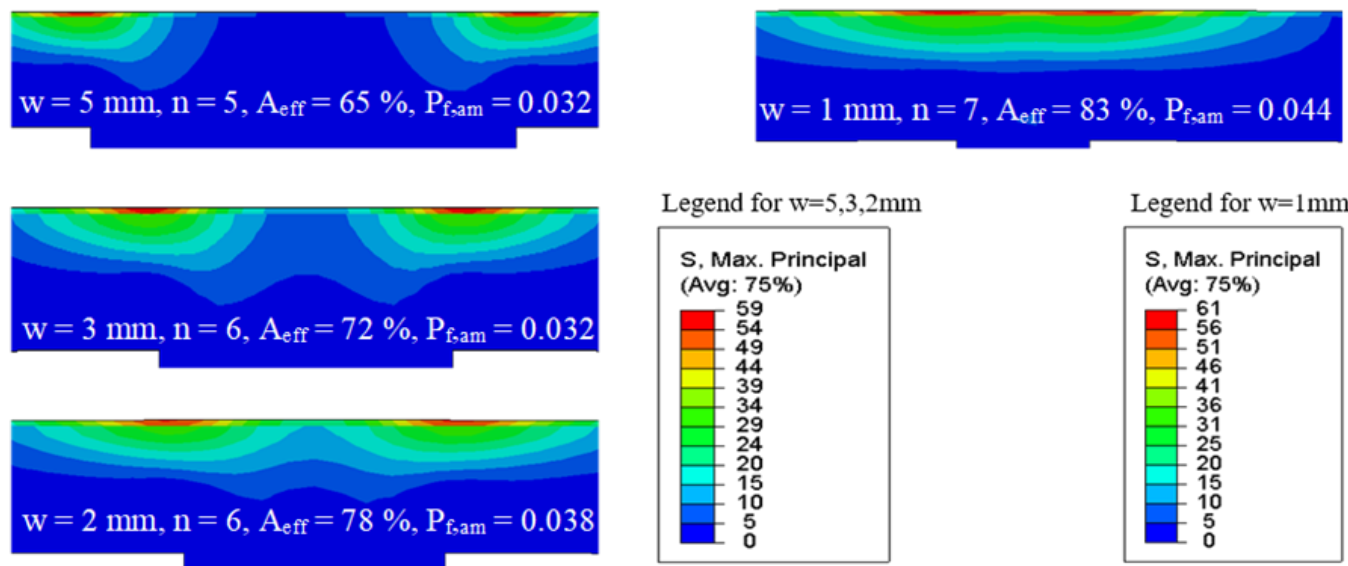

Figure 5: Maximum principal stress distribution in asymmetric LSCF membrane with different widths w of stability elements $w=5,3,2$ and $1 \mathrm{~mm} . p_{\text {feed }}=5$ bar.

A plot of the influence of stability element width $\mathrm{w}$ on the effective membrane area $\mathrm{A}_{\text {eff }}$ according to Equation 3 on the principal stress $\sigma_{I, \text { max }}$ in the ceramic is depicted in Figure 6 (left) in dependence of the feed gas pressure $\mathrm{p}_{\text {feed. }}$. The influence on failure portability $\mathrm{P}_{\mathrm{f}, \mathrm{am}}$ in dependence of $\mathrm{p}_{\text {feed }}$ is shown in Figure 6 (right). In general, approx. $20 \%$ of the membrane surface is lost through joining. This means that after joining only $80 \%$ of the effective membrane area is available. Reducing the width of the stability elements $\mathrm{w}$ to $1-2 \mathrm{~mm}$ reduces the loss of the effective membrane area. However, the loss is counterbalanced by the use of porous stability elements, which hinder the gas exchange between sweep gas and membrane, but do not completely block it. Cost estimates and process integration studies must show whether the loss of the effective membrane area is acceptable. 

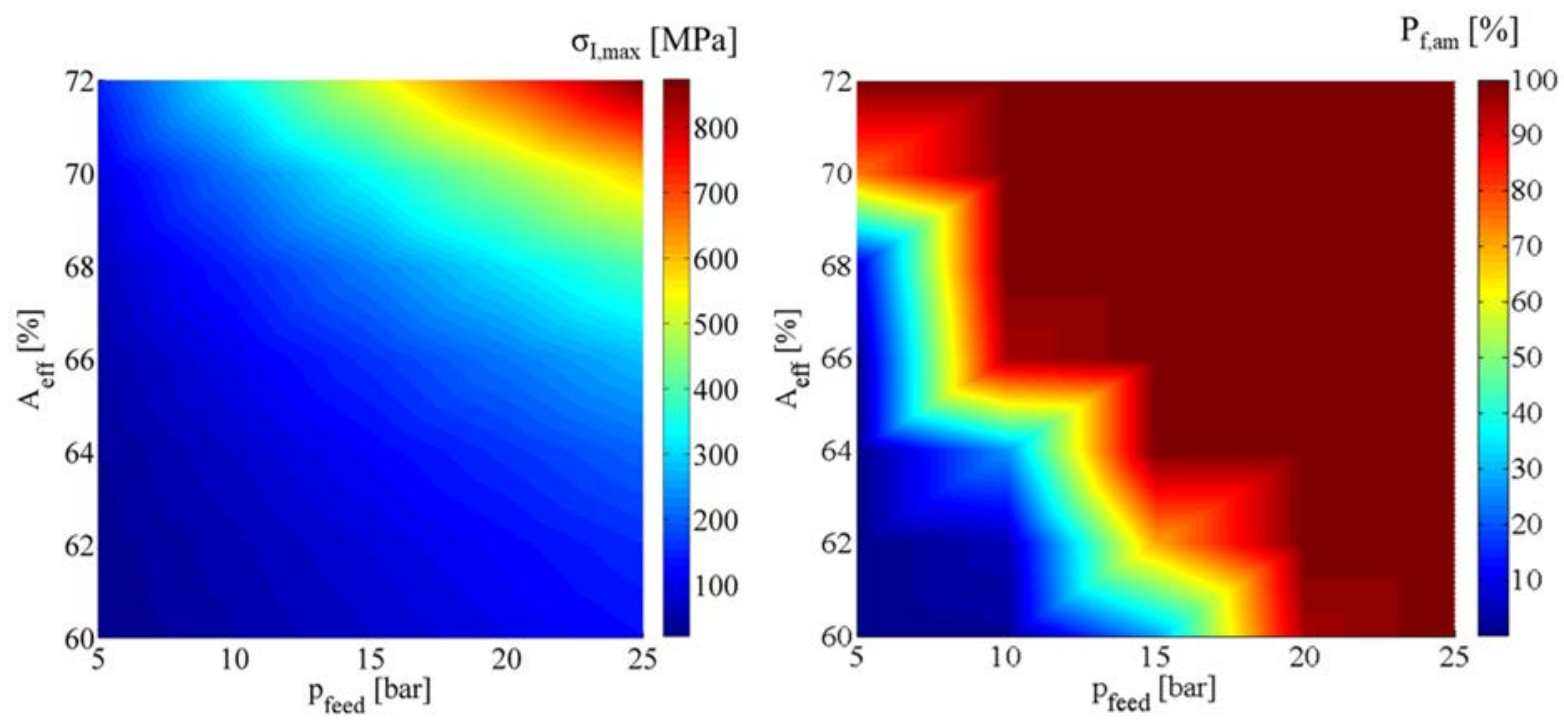

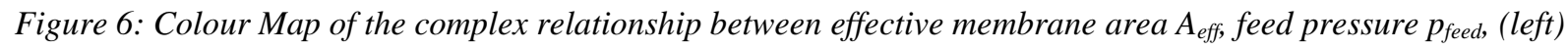
maximum principal stress $\sigma_{I, \max }\left(\right.$ left) and fracture probability $P_{f, a m}$ (right), respectively.

For the design of scalable components made of asymmetric membranes the FE-simulations had the following consequences:

- To yield a fracture probability of the membrane components below $0.01 \%$ the number of stability elements must be increased. For example simulations with $n=10, w=2 \mathrm{~mm}, x=6.3$ $\mathrm{mm}$ and $p_{\text {feed }}=5$ bar yielded $P_{f}=0.003 \%$.

- With regard to the challenges of a membrane component manufacturing and handling the design was fixed to $x=2 \mathrm{~mm}$ and $w=2 \mathrm{~mm}$ (c.f. Figure 17).

- Based on the simulation and from a manufacturing point of view, the number of stability elements ( $w=2 \mathrm{~mm}$ ) were further increased to 18 and 19 flow channels of the same width were used for a sample component with a width of $100 \mathrm{~mm}$. For the two sideways stability elements, a width of $w=13 \mathrm{~mm}$ was used to accommodate manufacturing tolerances and to ensure sufficient stability in the joining zone.

\section{Computational Fluid Dynamics analysis}

CFD simulations were performed in order to optimize fluid-dynamic regime inside the membrane module. The module consist of three membrane components, $10 \times 10 \mathrm{~cm} \times 3.9 \mathrm{~cm}$ in size, which are stacked according to Figure 1 (right). Each membrane component has a fixed geometry and size, defined according to the stress analysis results. Namely in each membrane component there are 18 stability elements $2 \mathrm{~mm}$ x $2 \mathrm{~mm}$. As a consequence, the active membrane area considered for permeation in the sweep side is reduced from $600 \mathrm{~cm}^{2}$ to $360 \mathrm{~cm}^{2}$. 
The objective of the simulations was to verify that the membrane module is able to reach an $\mathrm{O}_{2}$ concentration in the sweep gas $>23 \%$ and $\mathrm{O}_{2}$ recovery in the feed side $>80 \%$, according to the needs of the oxycombustion process. Simulated operating condition are summarized Table 3.

Table 3 Simulated operating conditions.

\begin{tabular}{ccccccc} 
& $\begin{array}{c}\mathbf{T} \\
{\left[{ }^{\circ} \mathbf{C}\right]}\end{array}$ & $\begin{array}{c}\text { Pressure } \\
{[\mathbf{b a r}]}\end{array}$ & $\begin{array}{c}\mathbf{O}_{2} \\
{[\%]}\end{array}$ & $\begin{array}{c}\mathbf{N}_{2} \\
{[\%]}\end{array}$ & $\begin{array}{c}\mathbf{C O}_{2} \\
{[\%]}\end{array}$ & $\begin{array}{c}\text { Flow rate } \\
{[\mathbf{N L} / \mathbf{h}]}\end{array}$ \\
\hline Feed & 850 & $5-8-10$ & 21 & 79 & - & $400-600$ \\
\hline Sweep & 850 & 1 & 3 & - & 97 & $200-400$ \\
\hline
\end{tabular}

More in detail, a first parametrization was done keeping a constant sweep gas flow rate at $300 \mathrm{NL} / \mathrm{h}$ and varying feed gas flow rate from 400 to $600 \mathrm{NL} / \mathrm{h}$, at 10 bar. Results indicate that design targets in terms of product $\mathrm{O}_{2}$ molar fraction and of $\mathrm{O}_{2}$ recovery are only met while working with a 2:1 feed/sweep gas flow rate $(600 / 300 \mathrm{NL} / \mathrm{h})$.

Accordingly, a second set of simulations was carried out by reducing simultaneously feed and sweep flow rates, while keeping the optimal feed/sweep flow rate ratio of two and the feed pressure at 10 bar. The results indicate that in all the simulations the target values are reached when using flow rates between $400 / 200$ to $600 / 300 \mathrm{NL} / \mathrm{h}$ for the feed/sweep gas, respectively. However, the best results are obtained by operating at the low flow rates $(400 / 200 \mathrm{NL} / \mathrm{h})$ resulting in a remarkable $\mathrm{O}_{2}$ concentration in the sweep gas of $30 \%$ and a recovery of the feed gas of $96 \%$.

Using these best operating conditions (feed/permeate flow rate of 400/200 NL/h), a third set of simulations was carried out by varying feed pressure. Namely it was considered the possibility to achieve design targets while reducing feed pressure down to 5 bar, i.e. the value established by stress analysis simulations. Results are shown in Figure 7. It can be noted that, the target values are met in the entire pressure range. Specifically, at $5 \mathrm{bar}$, an $\mathrm{O}_{2}$ concentration in the sweep gas of $27 \%$ and a recovery of the feed gas of $86 \%$ are achieved. These values, therefore, are considered for design purpose of the module.

Velocity and oxygen distribution inside the module at $\mathrm{p}=5$ bar are reported in Figure 8 . The gas flow is well-distributed in all the membrane components, both in the feed and in the sweep; in particular, the flow is uniformly split in the sweep channels and compartments. Consequently a uniform oxygen distribution in the feed gas and in the permeate gas throughout the module is obtained, thus allowing to obtain a high recovery in the feed (86\%). 


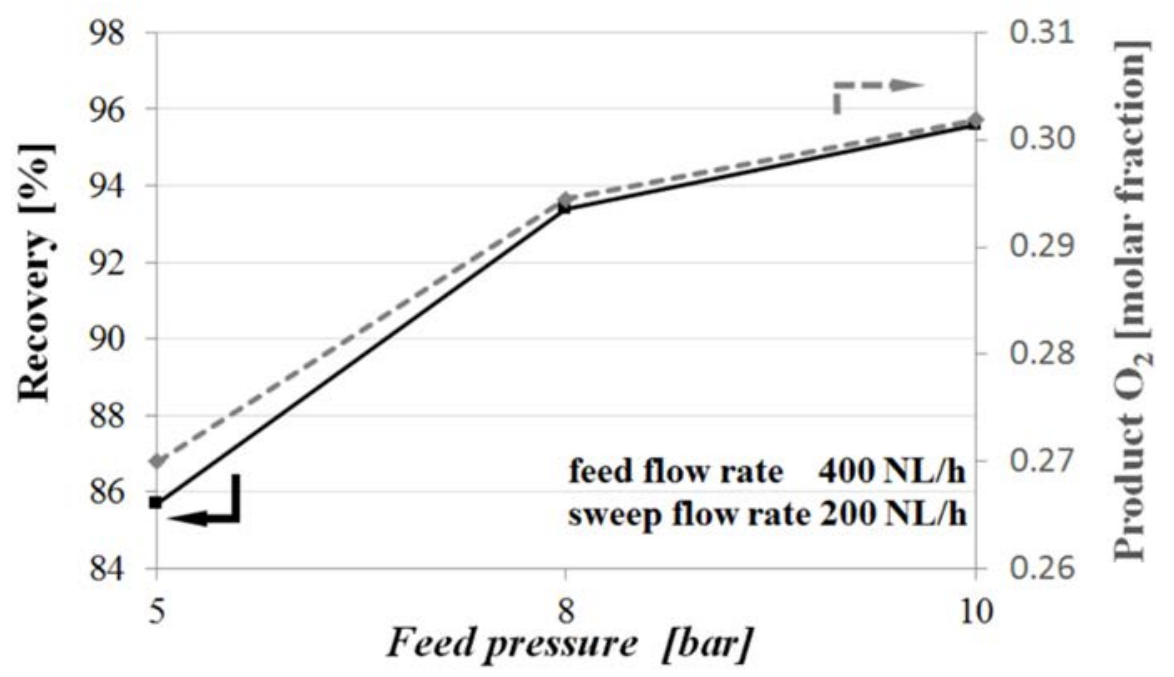

Figure 7: Product $\mathrm{O}_{2}$ molar fraction and $\mathrm{O}_{2}$ recovery as a function of feed pressure and 1 bar sweep pressure.

Feed gas

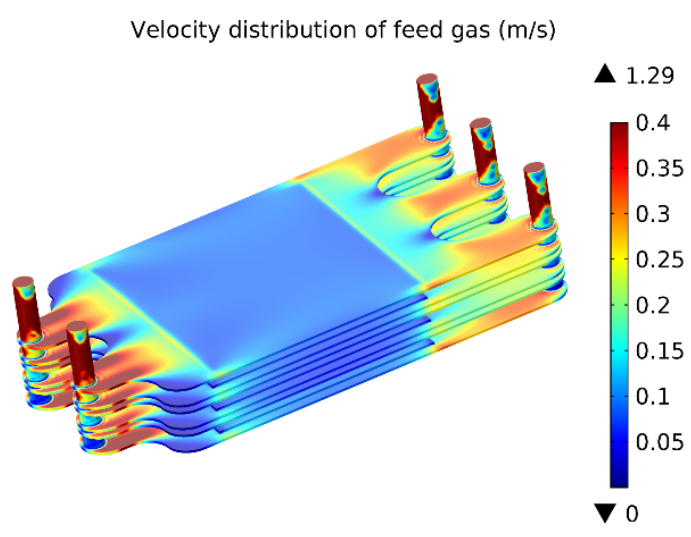

Feed $\mathrm{O}_{2}$ molar fraction

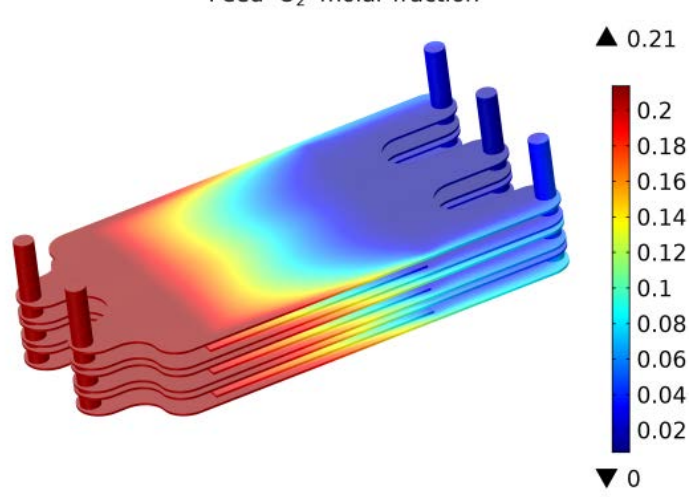

Sweep gas

Velocity distribution of sweep gas $(\mathrm{m} / \mathrm{s})$

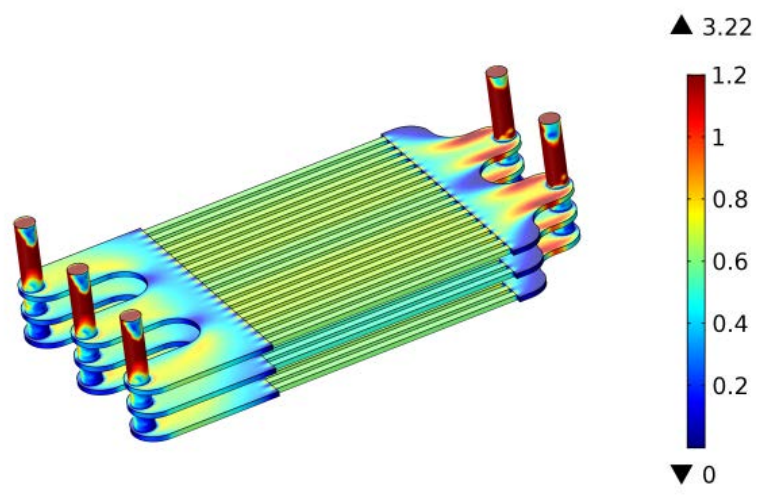

Permeate $\mathrm{O}_{2}$ molar fraction

$\mathbf{\Delta} 0.32$

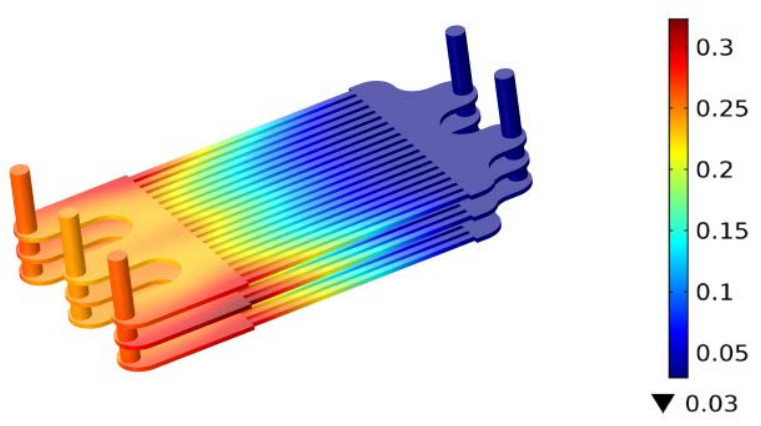

Figure 8: Velocity profiles and oxygen distribution in the feed and in the sweep gas, respectively, obtained at feed/permeate flow rate of 400/200 NL/h and at feed gas pressure of 5bar.

\section{Manufacturing}

In the design of the production process for membrane components, great emphasis was laid on the use of scalable processes that allow a possible industrial production as can be seen from the process flow chart in Figure 9. The component consists of two half-cells, each composed of an asymmetric membrane 
and an interlayer. Deviating from the simulation, the components were manufactured with a width of 70 $\mathrm{mm}$ and a length of $100 \mathrm{~mm}$ due to the available technical equipment, but the dimensions of the flow channel and stability elements were kept constant.

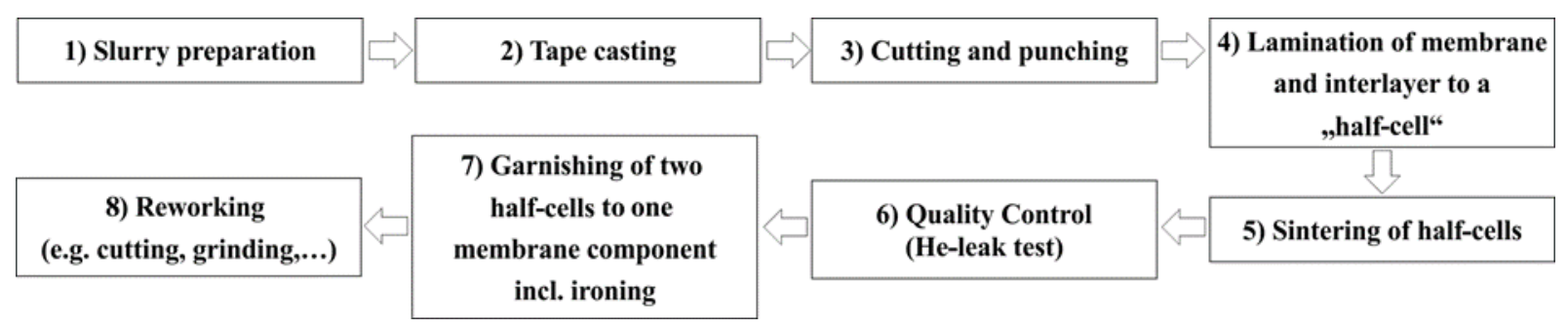

Figure 9: Process flow chart for membrane component manufacturing.

The manufacturing of components is based on the previously published development of asymmetric membranes [33, 34, 36, 37, 38, 39]. The following process steps were crucial for successful production of the desired large scale components: tape casting, sintering behavior, interlayer punching and laminating.

\section{Tape casting}

One of the most important measures during production is the quality assurance along the process chain. To obtain membranes with a low defect density, raw materials of reproducible quality and defined properties are indispensable for scale-up and a reliable process. Tape casting is a proven technology for large scale production of ceramic components and hence was chosen for manufacturing asymmetric membrane and interlayer foils. After the thin membrane layer has been cast, visual inspection for pinholes and other defects is carried out using a lamp underneath the membrane. While casting the interlayer slurry on top of the dried membrane layer, there is a risk that pinholes may form. Therefore, slurries, which are necessary for the process must ensure a stable dispersion of the powder, a homogenous drying of cast tapes. Is this not the case, the solvent seeps into the membrane layer and dissolves it, resulting in new defects in the membrane layer. To avoid this, a narrow particle size distribution of the powder is required, and the organic components must also be sufficiently dissolved in the solvent. This furthermore ensures a sufficient elasticity and strength of the tape for handling. The specific surface area of the ceramic powder used in this work for tape casting is less than $3 \mathrm{~m}^{2} / \mathrm{g}$, to ensure a proper dispersion of the powder by the use of dispersants and to avoid the re-agglomeration by weak interparticle forces, that is, van der Waals and H-bonds. The surface area can be obtained by controlling the particle size, which should be in the range of 1-10 $\mu \mathrm{m}$ (dependent on the materials density), which furthermore avoids sedimentation of large powder particles.

For tape casting a powder with dense grains, synthesized by solid state reaction, in which the corresponding carbonates or oxides were mixed and subsequent calcined at high temperature, were used. 
This results in large, dense particles with low surface area. These powders were further processed to gain a monomodal particle distribution with an average particle size $d_{50}$ of $2.2 \mu \mathrm{m}$ and a specific surface area $\mathrm{A}_{\text {spec }}$ of $0.9 \mathrm{~m}^{2}$. This powder (LSCF60 SSR) was delivered in R\&D batches by Solvay Flour GmbH, Germany.

Phase content of the powder was analyzed at room temperature in air by XRD. These powders showed at room temperature in air small amounts of orthorhombic and mainly rhombohedral perovskite structure. The orthorhombic phase can be explained by a too short dwell times or temperature to form the rhombohedral perovskite structure. After heat treatment in air at $1200{ }^{\circ} \mathrm{C}$ only the rhombohedral perovskite structure is obtained at room temperature. The aimed stoichiometry was confirmed by ICPOES within the exactness of the measurements of \pm 3 mol\%.

\section{Mechanical punching of interlayers}
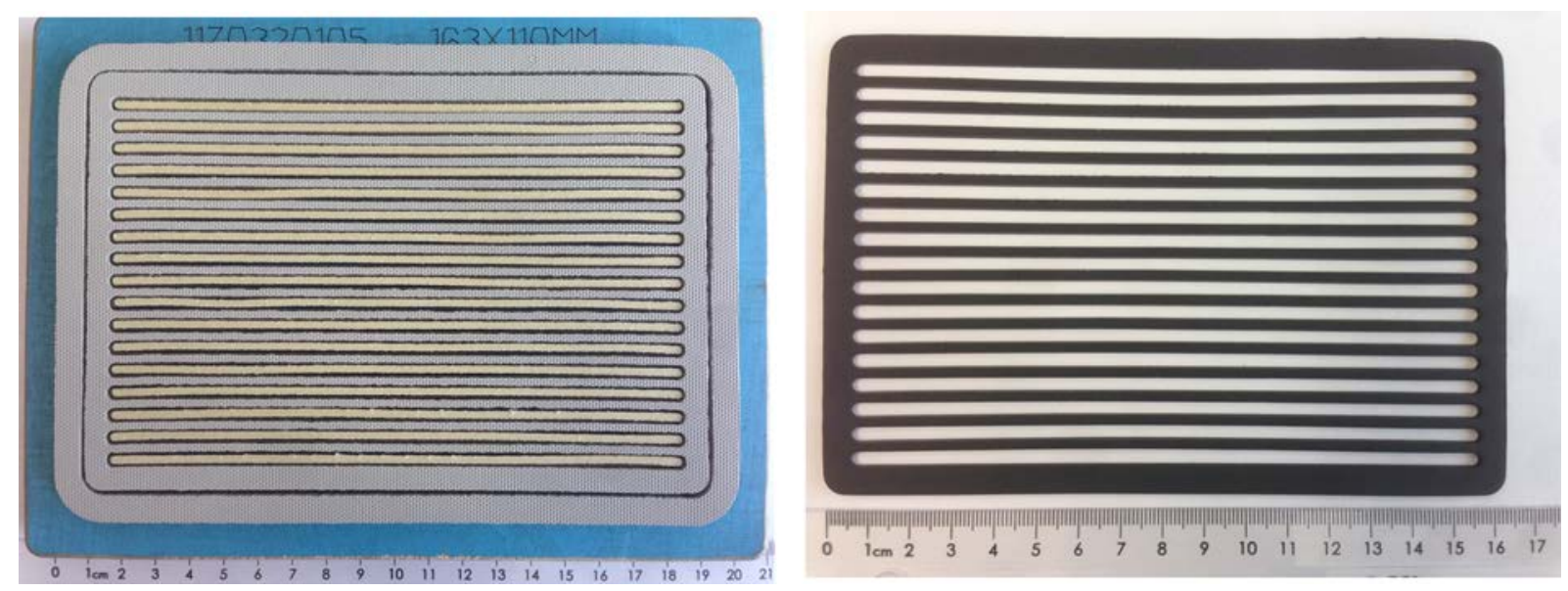

Figure 10: Punching tool and green interlayer $\left(110 \times 163 \mathrm{~mm}^{2}\right)$ for fabrication of $70 \times 100 \mathrm{~mm}^{2}$ membrane components.

Punching of the green interlayer tapes with a thickness of $1300 \mu \mathrm{m}$ was performed on a hydraulic press in order to shape the flow channels, necessary for gas transport trough the later component. Shaping green tapes in these dimensions is beyond the limits of punching process, due to the ratio of tape thickness to width of the flow channels which is nearly 1:2. This can easily lead to burrs or cracks during punching, requiring careful process control [40].

Due to the high plastic deformability of the tape, punching of 17 flow channels with a width of $2.9 \mathrm{~mm}$ and $150 \mathrm{~mm}$ in length in green state was possible. The tool (Karl Marbach GmbH, Germany) and the resulting interlayer foil is shown in Figure 10. A force of $250 \mathrm{kN}$ with a holding time of $10 \mathrm{~s}$ was required for cutting the foils. The loading rated proved to be decisive for the dimensional accuracy of the channel cross-sections. When the loading rate is $>50 \mathrm{kN} / \mathrm{s}$, the cross-sections showed good shape accuracy. 
Below $50 \mathrm{kN} / \mathrm{s}$, the blades have bent to the channel side with increasing cutting depth and the channel cross-section has become trapezoidal.

The reason for the deformation behavior of the green tape is the high content of $12 \mathrm{vol} \%$ binder (polymer) and 35 vol\% corn starch, forming a percolating and plastically deformable network. Analogous to plastics, the viscoelastic deformation behavior of the tape depends on the loading rate. The high loading rate suppresses flowing and at the same time the strain to rupture is reduced considerably, causing the tape to become brittle under pressure.

\section{Lamination}

In contrast to cutting, plastic deformation and creep are desired during lamination using the thermocompression method [41]. First the green tapes are stacked and subsequently heated above the glass transition temperature of the binder $\left(72-78^{\circ} \mathrm{C}\right.$ ) but below the softening point (approx. $135^{\circ} \mathrm{C}$ ) [42]. A force is applied onto the heated stack in order to enable viscous flow of the polymer phase resulting in interpenetration of the particles between the different tape layers.

Especially for the inhomogeneous structure, such as the interlayer with its channel structure, the pressure distribution is inhomogeneous around the cavities of the channels. Therefore one concern is the dimensional stability of the structure. This makes a careful choice of the temperature necessary. Choosing a too low temperature, the viscous flow of the polymeric binder does not take place and cracks can from at the transition from asymmetric membrane support to the interlayer channel. If the selected temperature is too high, sufficient viscous flow occurs, but the softening of the tape can cause the membrane layer to sag. The best dimensional stability and was achieved at temperatures between 80 and $90^{\circ} \mathrm{C}$.

Besides temperature control, process control is an important component for the production of laminates. On the one hand, the tape can delaminate; on the other hand, the membrane layer can sag at too high temperatures and thus lead to delamination, when the force of the press is released. This phenomenon is depicted in Figure 11 (left-top). To avoid this, the lamination program was run in such a way that first the tapes are heated, then the pressure is applied and kept while the laminate cools down. The press tool is not opened again until the temperature is below $40^{\circ} \mathrm{C}$ (c.f. Figure 11 right). The resulting channel cross section is depicted in Figure 11 (left-bottom). 

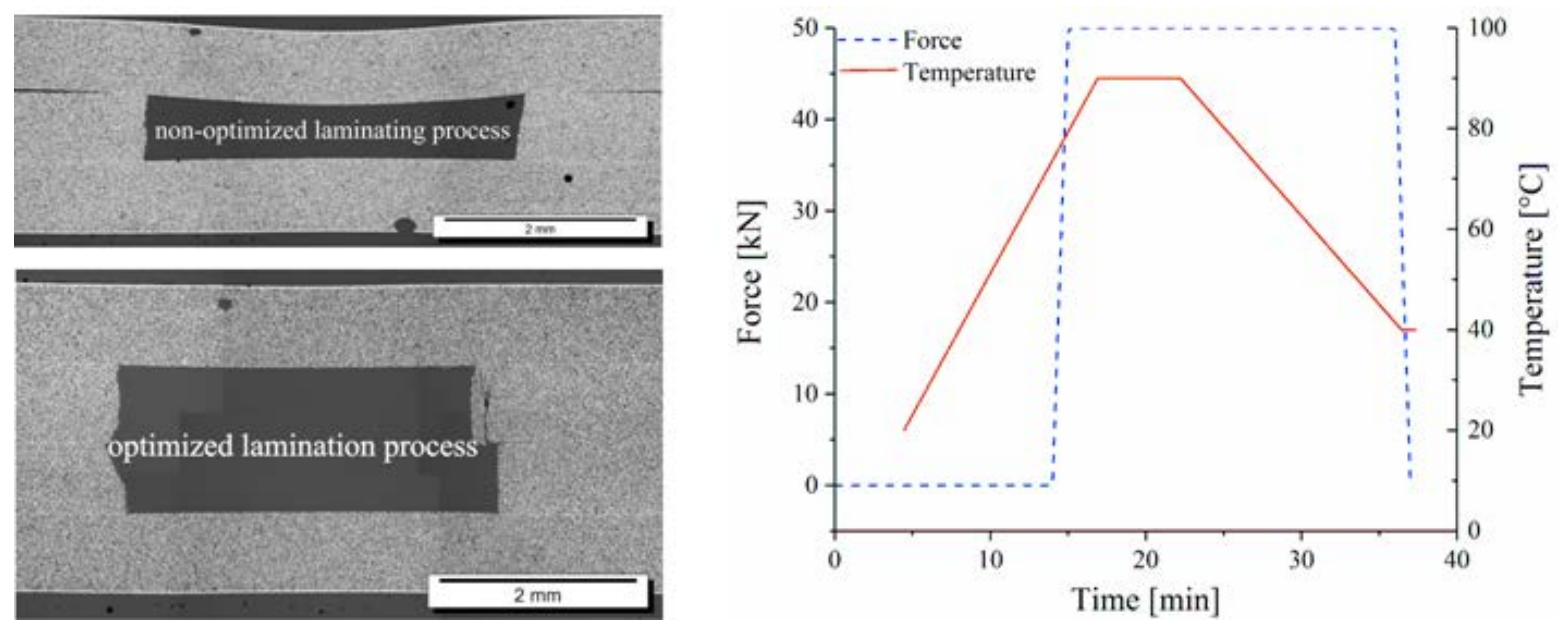

Figure 11: Left-top: Cross section of an already sintered laminate, processed at $100{ }^{\circ} \mathrm{C}$ without process optimization, and left-bottom with process optimization. Right: Optimized temperature-force-lamination program to avoid delamination of the tapes.

Since the plastic deformation of the green tapes is limited even above the glass transition temperature, the travel distance of the force-controlled press was limited by spacers. Limiting the compression to 7\% of the thickness made a good compromise here. The quality of the lamination was evaluated based on the connection of the different layers of the half cell.

\section{Debinding and sintering of half cells}

The burn out of the organic components in combination with the catalytic activity of the LSCF material is problematic due to the unintentional spontaneous ignition of the tape while heating and results in complete destruction of the cells (c.f. Figure 12 - left). The ignition point of the tape is located between 200 and $300{ }^{\circ} \mathrm{C}$, which is marked in the DTA/TG plot in Figure 12 (right) by the red dot, followed by a sharp exothermal peak, reflecting the released energy. Therefore, for successful debinding a very slow heating rate, until the organic components are burned out at around $400{ }^{\circ} \mathrm{C}$, is desired.
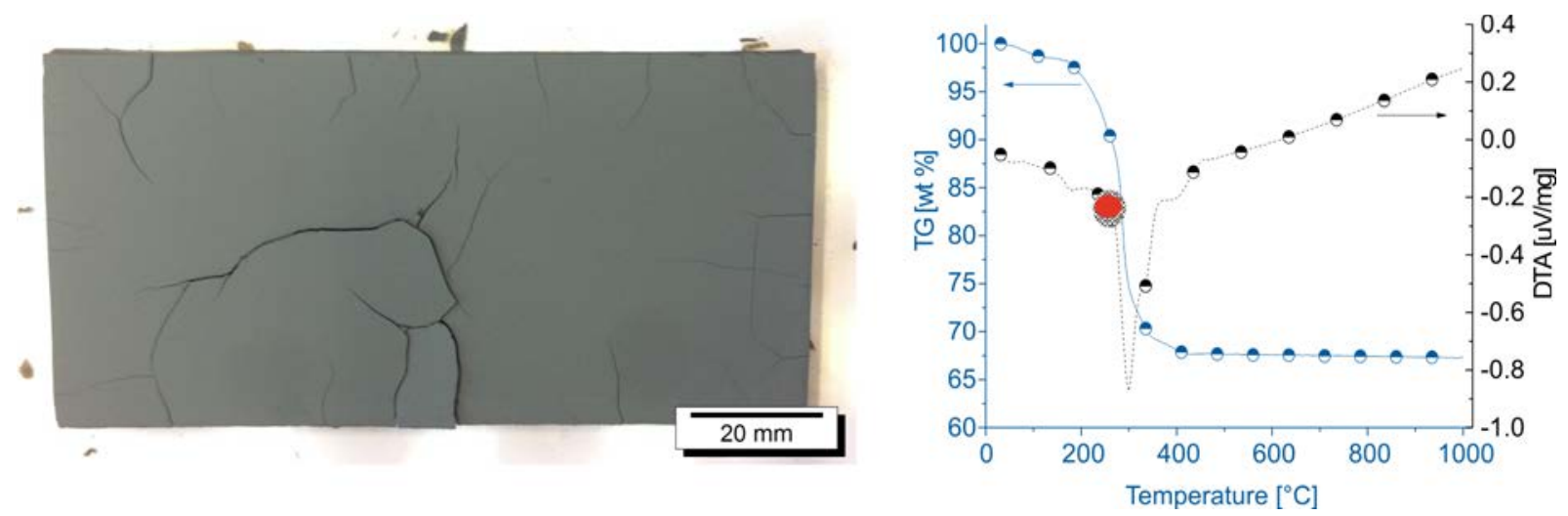

Figure 12: Left: destructed component during heat treatment caused by ignition. Right: Mass loss (TG) and energy release and uptake (DTA) of a component while heat treatment with constant heating rate of $3 \mathrm{~K} / \mathrm{min}$. 


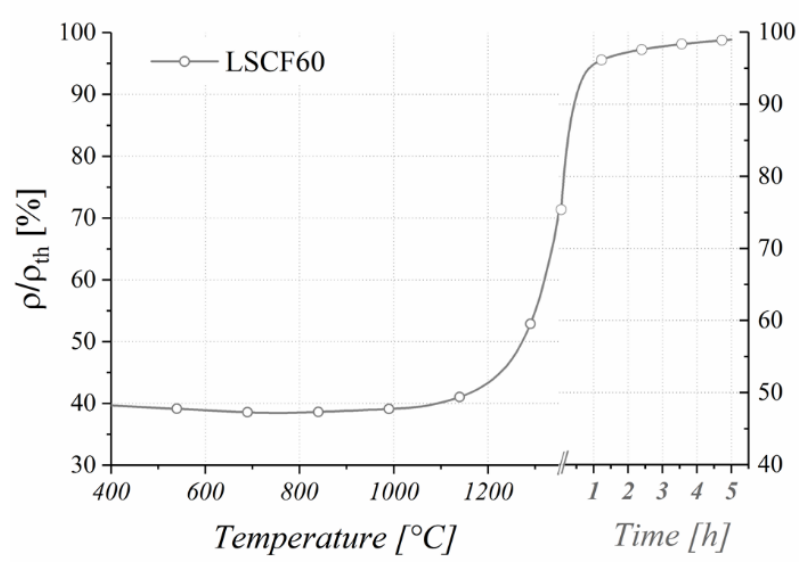

Figure 13: Relative density of the LSCF60 SSR powder pellet used for tape casting, up to a temperature of $1350^{\circ} \mathrm{C}$ with a heating rate of $5 \mathrm{~K} / \mathrm{min}$.

The final sintering temperature of the half cells depends on the sintering activity of the ceramic powder, which is a function of specific surface area, particle morphology and size. The sintering behavior of pressed pellets with comparable green density is plotted in Figure 13. In order to achieve a sufficiently high densification of the membrane layers produced by sequential tape casting from LSCF60 powder, it is necessary to increase the sintering temperature to, at least, $1300^{\circ} \mathrm{C}$ (c.f. Figure 13). A dwell time of 5 $\mathrm{h}$ results in a relative density $\rho_{\text {rel. }}$ of $>99 \%$. The microstructural evolution of an asymmetric membrane in dependence of the final sintering temperature is shown on cross sections in Figure 14 for a dwell time of 5 h.

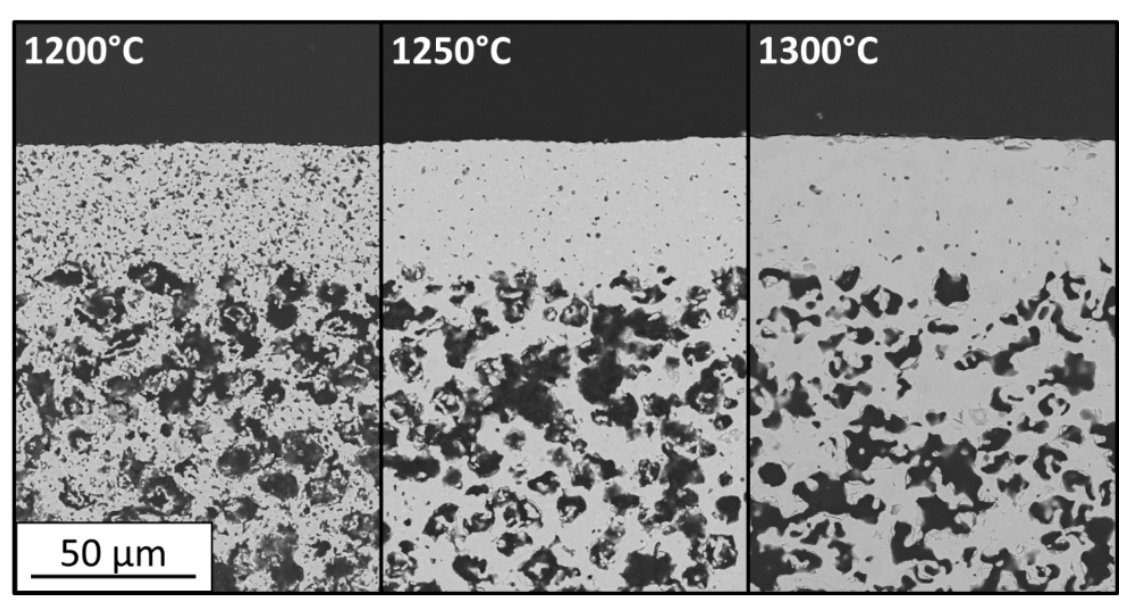

Figure 14: Densification of asymmetric membrane and support, made from LSCF60 powder, at different temperatures and a dwell time of $5 \mathrm{~h}$.

The selection of sufficient sintering parameters ensure a thin, pore free membrane and a maximized support porosity. Since both differ in sintering activity (due to the pore-forming agents in the support tape), membrane layer and support are shrinking with different rates, which results in deflection of half cells [43]. An optimal result in terms of deflection and densification was obtained with a dwell time of 
$5 \mathrm{~h}$ at $1300^{\circ} \mathrm{C}$. After this dwell time the support shows an about $5 \%$ higher linear shrinkage compared to the membrane layer, as shown in Figure 15 (left). This additional support shrinkage is a driving force for densification of the membrane layer. As shown in Figure 15 (right), on the basis of the decomposition characteristics of the organic material, the debinding process is very slow at the beginning, whereby the heating rate is slightly increased up to $900^{\circ} \mathrm{C}$ in the process. From $900^{\circ} \mathrm{C}$ the heating rate is significantly increased in order not to lose any sintering activity. The residual porosity inside the membrane layer and the support is less than $2 \%$ and $38 \%$ respectively, without causing any noticeable deflection of the halfcell.
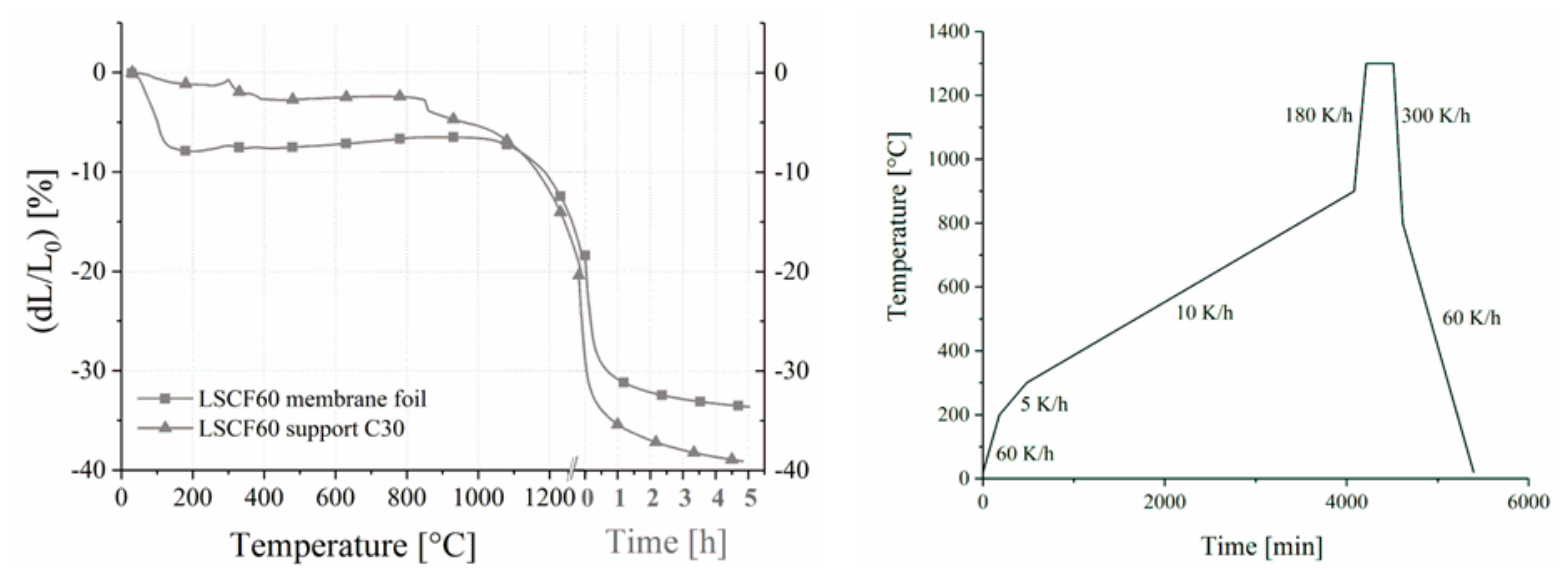

Figure 15: Left: Linear shrinkage of green tapes from LSCF60 SSR (Solvay) powder in air as function of temperature and time with a heating rate of $5 \mathrm{~K} / \mathrm{min}$. Right: Sintering program for half-cell production.

For reasons of quality assurance the leakage due to defects such as pinholes in the membrane layer was measured using He-leakage tests (Pfeiffer Vacuum GmbH, HLT260) on half-cells. Assuming an average $\mathrm{O}_{2}$ flux of $0.5 \mathrm{ml} /\left(\mathrm{min} \mathrm{cm}^{2}\right)$ and a minimal desired oxygen purity of $98 \%$, the tolerable He-leakage at ambient pressure and room temperature for $7 \times 10 \mathrm{~cm}^{2}$ is $0,015 \mathrm{mbar} \cdot 1 / \mathrm{s}$. Only sintered half cells with a He-leakage below the resulting threshold of $2 \times 10^{-4} \mathrm{mbar} \cdot 1 /\left(\mathrm{s} \cdot \mathrm{cm}^{2}\right)$ were further processed by garnishing.

\section{Garnishing}

For the garnishing of the already sintered half cells to a component, a paste containing spray dried powder LSCF58 was used between two half cells. Powders produced by spray pyrolysis possess a high surface area and a lower sintering temperature [44], compared to the LSCF60 SSR powder, as depicted in Figure 16. 


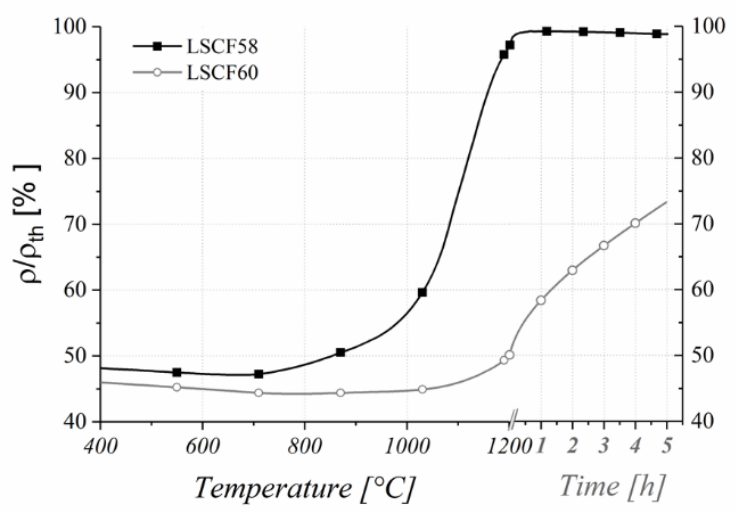

Figure 16: Relative density of pressed pellets made from the different LSCF powders, measured in air as function of temperature up to $1200^{\circ} \mathrm{C}$.

The paste was applied to the interlayer-side by use of a rubber roll. Two half cells were combined with the interlayer faces to each other and were sintered at $1200^{\circ} \mathrm{C}$ for $5 \mathrm{~h}$. In addition, the two half cells were loaded with a weight of $500 \mathrm{~g}$, during heat treatment, in order to flatten the component.

\section{Membrane components and microstructure}

Figure 17 shows the gas-tight (He-leakage below $4 \times 10^{-4} \mathrm{mbar} \cdot 1 /\left(\mathrm{s}^{\cdot} \mathrm{cm}^{2}\right)$ ) and easy-to-handle membrane components for use in 4-end operation under oxy-combustion conditions. Due to the available equipment for tape casting, membrane components with a final width of $70 \mathrm{~mm}$ and $100 \mathrm{~mm}$ length were produced. However, the process (Figure 9) can be transferred to plants of industrial size in order to manufacture membrane components with larger dimensions. These components consist of a thin membrane layer with a thickness of $\sim 20 \mu \mathrm{m}$ on the outside, onto a thin porous activation layer is applied (thickness $=3-5 \mu \mathrm{m}$ ) to increase the surface area for oxygen exchange reactions (c.f. Figure 18 (top)). Underneath the membrane layer is the membrane support with a thickness of $900 \mu \mathrm{m}$ and a porosity of $38 \%$. The closed porosity was determined by Archimedes' method according to [45] and amounts to 8 $\%$. Thus the open porosity is $30 \%$ and is clearly above a necessary percolation limit. As confirmed by X-ray computed tomography studies on $\mathrm{Ba}_{0.5} \mathrm{Sr}_{0.5}\left(\mathrm{Co}_{0.8} \mathrm{Fe}_{0.2}\right)_{0.97} \mathrm{Zr}_{0.3} \mathrm{O}_{3-\delta}$ membranes with a similar microstructure, the pore channels of such tape-cast supports are well interconnected [46, 47]. However, it can be assumed that the tortuosity of the pore channels is also increased by increasing the proportion of closed porosity. This affects the path length for gas transport through the support, which has a negative effect on oxygen transport. In addition, the pore opening diameters also influence the gas transport, which can result in insufficient gas exchange and thus concentration polarization in the support $[48,49,50]$. 


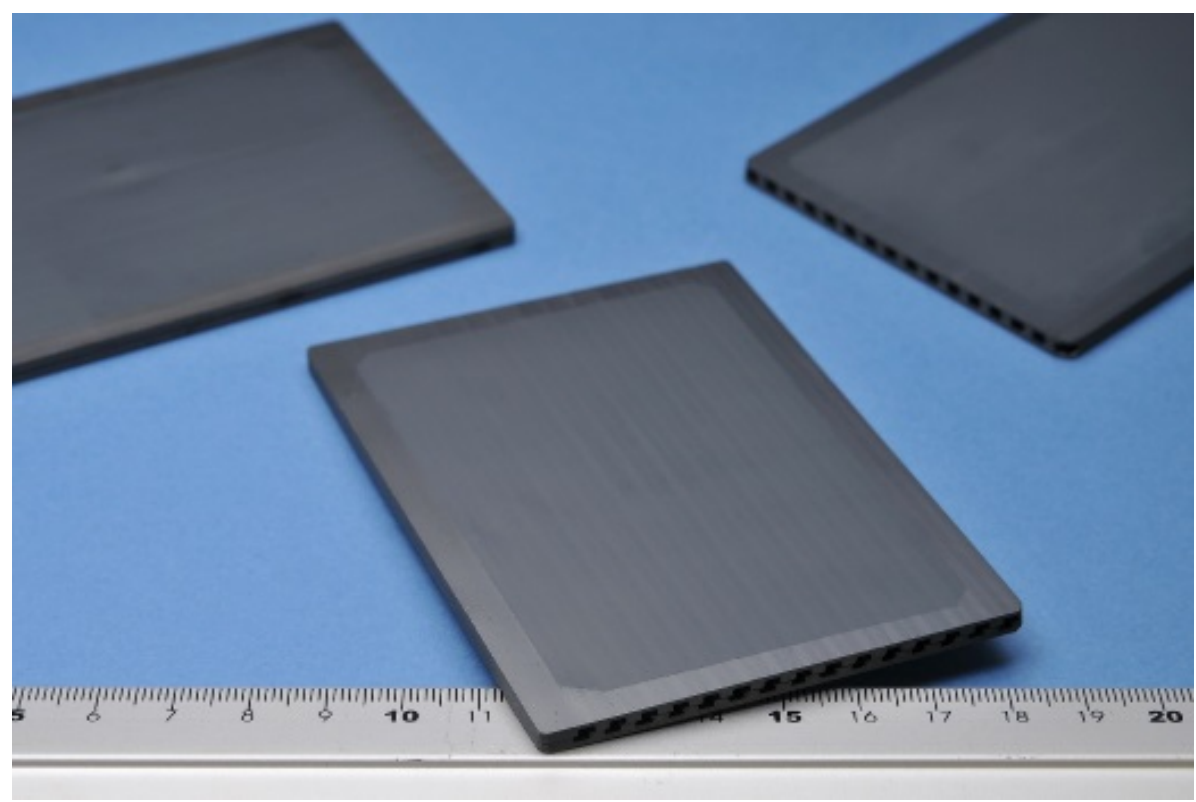

Figure 17: Final membrane components in the dimension $70 \times 100 \mathrm{~mm}^{2}$.

As can be seen in Figure 18 (bottom), there is potential for optimization. The lamination parameters temperature, pressure and dwell time as well as the thickness tolerance of the green foils can be improved in order to avoid cavities between the stability elements and the asymmetric membrane and hence improve mechanical strength.

The application of the paste to garnish the half cells is also worthy of improvement. The contact pressure of the rollers can be controlled and adjusted to the viscosity of the pastes. This would result in the production of a homogeneous coating of the garnishing paste on the interlayers in order to connect the two half cells over a large area. Furthermore, avoiding excess paste, pressed into the flow channels, would improve the gas flow.

With an increasing number of half cells for garnishing, there would be a greater number of possible combinations of these, which would reduce the misalignment of the stability elements. However, the shape accuracy of the half cells can already be improved by adjusting the lamination parameters as described above. 


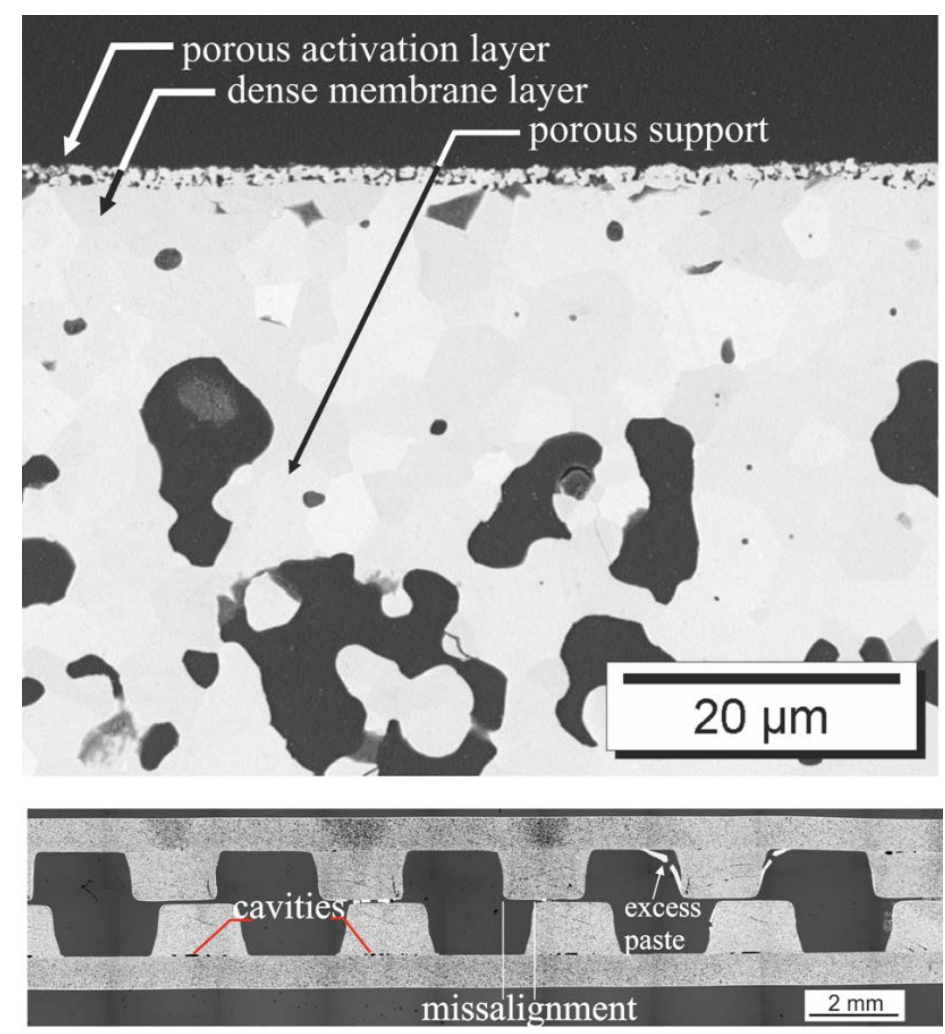

Figure 18: SEM detail image of the membrane layer (top) and light microscope image of the component crosssection (bottom).

\section{Conclusion}

The development of the planar membrane component design based on FEM and CFD simulations. The compromise between gas flow resistance (open cross-sectional area) and fracture probability (bending width) leads to a constructive compromise where flow channels and stability elements with a square cross-section of $2 \mathrm{~mm}$ width and height are used. Components of this type, operating at a feed pressure of $5 \mathrm{bar}$, have a fracture probability of less than $0.01 \%$. The $\mathrm{O}_{2}$ concentration in the permeate gas and $\mathrm{O}_{2}$ recovery from the feed gas at 5 bar feed pressure and $850{ }^{\circ} \mathrm{C}$ is $27 \%$ and $86 \%$ respectively.

The production chain developed is based on scalable manufacturing technologies that have been proven in mass production and are applicable in theory to other membrane material systems. However, the high number of process steps makes production prone to high reject rates and requires very tight process control. Ceramic powders according to industrial standards are essential for reproducible results. The completed membrane components, with a dimension of $70 \times 100 \mathrm{~mm}^{2}$, showed helium leakages below $4 \times 10^{-4} \mathrm{mbar} \cdot \mathrm{l} /\left(\mathrm{s} \cdot \mathrm{cm}^{2}\right)$ and outer dimensional tolerances $<100 \mu \mathrm{m}$.

\section{Acknowledgement}

We are grateful for the financial support received from the European Commission in the framework of the GREEN-CC Project (Grant Agreement no. 608524). The authors would also like to thank Stefan Heinz, Tobias Offermanns, Mark Kappertz and Ao Zhang for their technical support. 
1 M. Anheden, U. Burchhardt, H. Ecke, R. Faber, O. Jidinger, R. Giering, H. Kass, S. Lysk, E. Ramström, J. Yan, Overview of Operational Experience and Results from Test Activities in Vattenfall's 30 MWth Oxyfuel Pilot Plant in Schwarze Pumpe. Energy Procedia 4 (2011) 941-950. doi:10.1016/j.egypro.2011.01.140

2 M. Puig-Arnavat, M. Søgaard, K. Hjuler, J. Ahrenfeldt, U.B. Henriksen, P.V. Hendriksen, Integration of oxygen membranes for oxygen production in cement plants. Energy 91 (2015) 852-865. http://dx.doi.org/10.1016/j.energy.2015.08.109

3 P. Maas, N. Nauels, L. Zhao, P. Markewitz, V. Scherer, M. Modigell, D. Stolten, J.-F. Hake, Energetic and economic evaluation of membrane-based carbon capture routes for power plant processes. Int. J. Greenh. Gas Contr. 44 (2016) 124-139. http://dx.doi.org/10.1016/j.ijggc.2015.11.018

4 L.L. Anderson, P.A. Armstrong, R.R. Broekhuis, M.F. Carolan, J. Chen, M.D. Hutcheon, C.A. Lewinsohn, C.F. Miller, J.M. Repasky, D.M. Taylor, C.M. Woods, Advances in ion transport membrane technology for oxygen and syngas production. Solid State Ionics 288 (2016) 331-337. http://dx.doi.org/10.1016/j.ssi.2015.11.010

5 R. Kriegel, W. Burckhardt, I. Voigt, M. Schulz, E. Sommer, Benefits of the vacuum process for oxygen production from air using $\mathrm{Ba}_{0.5} \mathrm{Sr}_{0.5} \mathrm{Co}_{0.8} \mathrm{Fe}_{0.2} \mathrm{O}_{3-\delta}$ membranes. Intern. Conference on Inorganic Membranes, Tokyo, Japan, August 18 - 22, 2008. ISBN 978-4904353-01-1

6 J.M. Repasky, L.L. Anderson, E.E. van Stein, P.A. Armstrong, E.P. Foster, ITM Technology: Scale-up towards clean energy applications, Int. Pittsburgh Coal Conference 2012, Pittsburgh, PA, U.S.A, 15-18 October 2012.

7 M. Anheden, J. Yan, G. De Smedt, Denitrogenation (or Oxyfuel Concepts), Oil \& Gas Science and Technology - Rev. IFP, 60 (2005) 485-495. https://doi.org/10.2516/ogst:2005030

8 P. Maas, N. Nauels, L. Zhao, P. Markewitz, V. Scherer, M. Modigell, D. Stolten, J.-F. Hake, Energetic and economic evaluation of membrane-based carbon capture routes for power plant processes, Int. J. Greenhouse Gas Control, 44 (2016) 124-139. https://doi.org/10.1016/j.ijggc.2015.11.018

9 D. Shin, S. Kang, Numerical analysis of an ion transport membrane system for oxy-fuel Combustion, Appl. Energy 230 (2018) 875-888. https://doi.org/10.1016/j.apenergy.2018.09.016

10 R. Kriegel, L. Kiesel, R. Kircheisen, U. Pippardt, Performance of various archetypes of oxygen membranes for local oxygen supply, 93 ${ }^{\text {rd }}$ Annual Meeting and Symposium on High Performance Ceramics, 10.-13.4.2018 Munich, Germany.

11 R. Kriegel, Sauerstoff für die motorische Nutzung von Schwachgasen, Int. Bio- und Deponiegas Fachtagung \& Ausstellung, 18.-22.04.2016, Lübeck, Germany, Proceedings 153-171.

12 S. Baumann, J.M. Serra, M.P. Lobera, S. Escolástico, F. Schulze-Küppers, W.A. Meulenberg, Ultrahigh oxygen permeation flux through supported $\mathrm{Ba}_{0,5} \mathrm{Sr}_{0,5} \mathrm{Co}_{0,8} \mathrm{Fe}_{0,2} \mathrm{O}_{3-\delta}$ membranes, J. Membr. Sci. 377 (2011) 198-205.

13 D.K. Ramachandran, M. Søgaard, F. Clemens, J. Gurauskis, A. Kaiser, Fabrication and performance of a tubular ceria based oxygen transport membrane on a low cost MgO support, Sep. Purif. Technol. 147 (2015) 422430. http://dx.doi.org/10.1016/j.seppur.2015.02.037

14 S. Pirou, J.M. Bermudez, P. Vang Hendriksen, A. Kaiser, T. Ramirez Reina, M. Millan, R. Kiebach, Stability and performance of robust dual-phase $\left(\mathrm{ZrO}_{2}\right)_{0.89}\left(\mathrm{Y}_{2} \mathrm{O}_{3}\right)_{0.01}\left(\mathrm{Sc}_{2} \mathrm{O}_{3}\right)_{0.10}-\mathrm{Al}_{0.02} \mathrm{Zn}_{0.98} \mathrm{O}_{1.01}$ oxygen transport membranes, J. Membr. Sci. 543 (2017) 18-27. https://doi.org/10.1016/j.memsci.2017.08.044.

15 S. Pirou, J. Gurauskis, V. Gil, M. Søgaard, P. Vang Hendriksen, A. Kaiser, S. Ovtar, R. Kiebach, Oxygen permeation flux through $10 \mathrm{Sc} 1 \mathrm{YSZ}-\mathrm{MnCo}_{2} \mathrm{O}_{4}$ asymmetric membranes prepared by two-step sintering, Fuel Process. Technol. 152 (2016) 192-199. https://doi.org/10.1016/j.fuproc.2016.06.019

16 W. Xing, M.-L. Fontaine, Z. Li, J. M. Polfus, Y. Larring, C. Denonville, E. Nonnet, A. Stevenson, P. P. Henriksen, R. Bredesen, Asymmetric tubular CaTi0.6Fe0.15Mn0.25O3- $\delta$ membranes: Membrane architecture and long-term stability, J. Membr. Sci.548 (2018) 372-379. https://doi.org/10.1016/j.memsci.2017.11.042 
17 M. Jacobs, M.-L. Fontaine, R. Bredesen, B. Michielsen, V. Middelkoop, Y. Larring, F. Snijkers, Surface activation of asymmetric $\mathrm{CaTi}_{1-x} \mathrm{Fe}_{x} \mathrm{O}_{3-\delta}$ tubular membranes for oxygen separation, J. Membr. Sci. 477 (2015) 58-64. https://doi.org/10.1016/j.memsci.2014.12.019.

18 L. Rosen, N. Degenstein, M. Shah, J. Wilson, S. Kelly, J. Peck, M. Christie, Development of Oxygen Transport Membranes for Coal-Based Power Generation, Energy Proc. 4 (2011) 750-755. https://doi.org/10.1016/j.egypro.2011.01.115

19 J. Li, OTM-Enhanced Coal Syngas for Carbon Capture Power Systems and Fuel Synthesis Applications, DOE/NETL Gasification Systems Program Portfolio Review Meeting, Pittsburgh, US, 20 March 2017.

20 Z. Lu, P.J. Plonczak J.A. Lane, Composite oxygen ion transport membrane, U.S. Patent application publication US 2016,0096150A1, April 7., 2016.

21 M. Schulz, U. Pippardt, L. Kiesel, K. Ritter, R. Kriegel, Oxygen Permeation of Various Archetypes of Oxygen Membranes Based on BSCF, AIChE Journal 58 (2012) 3195-3202. https://doi.org/10.1002/aic.13843

22 E.M. Pfaff, A. Kaletsch, C. Broeckmann, Design of a mixed ionic/electronic conducting oxygen transport membrane pilot module, Chem.Eng.Technol. 35 (2012) 455-463. https://doi.org/10.1002/ceat.201100447

23 N. Nauels, S. Herzog, M. Modigell, C. Broeckmann, Membrane module for pilot scale oxygen production, J. Mem. Sci. 574 (2019) 252-261. https://doi.org/10.1016/j.memsci.2018.12.061

24 D. Munz; T. Fett, Mechanical Properties, Failure Behaviour, Materials Selection, Springer Berlin Heidelberg (1999). doi: 10.1007/978-3-642-58407-7

25 B.X. Huang, J. Malzbender, R.W. Steinbrech, L. Singheiser, Mechanical properties of $\mathrm{La}_{0.58} \mathrm{Sr}_{0.4} \mathrm{Co}_{0.2} \mathrm{Fe}_{0.8} \mathrm{O}_{3-\delta}$ membranes, Solid State Ionics 180 (2009) 241-245. https://doi.org/10.1016/j.ssi.2008.11.005

26 E. Pfaff, M. Oezel, A. Eser, A. Bezold, Reliability of ceramic membranes of BSCF for oxygen separation in a pilot membrane reactor, 10th Pacific Rim Conference on Ceramic and Glass Technology 2013, San Diego, CA, U.S.A, 2.-7. June 2013.

27 M. Asmani, C. Kermel, A. Leriche, M. Ourak, Influence of porosity on Young's modulus and Poisson's ratio in alumina ceramics, J. Europ. Ceram. Soc. 21 (2001) 1081-1086. https://doi.org/10.1016/S0955-2219(00)00314-9

28 A. Kaletsch, Reaktivlöten von Perowskit-Stahl-Verbunden und deren Alterungsbeständigkeit in oxidierender Atmosphäre, Shaker Verlag, Aachen, 2016. ISBN: 978-3-8440-4257-3

29 Nicrofer® 6025 HT - alloy 602 CA, Material Data Sheet No. 4037, Thyssen Krupp VDM (2007).

30 Inconel alloy 601 - Material Data Sheet SMC-028, Special Metals (2005)

31 M.M. Abdel-jawad, S. Gopalakrishnan, M.C. Duke, M.N. Macrossan, P. SmithSchneider, J.C. Diniz da Costa, Flowfields on feed and permeate sides of tubular molecular sieving silica (MSS) membranes, J. Membr. Sci. 299 (2007) 229-235. https://doi.org/10.1016/j.memsci.2007.04.046

32 G. Ji, G. Wang, K. Hooman, S. Bhatia, J.C. Diniz da Costa, Computational fluid dynamics applied to high temperature hydrogen separation membranes, Front. Chem. Sci. Eng. 6 (2012) 3-12. https://doi.org/10.1007/s11705-011-1161-5

33 J.M. Serra, J. Garcia-Fayos, S. Baumann, F. Schulze-Küppers, W.A. Meulenberg, Oxygen permeation through tape-cast asymmetric all- $\mathrm{La}_{0.6} \mathrm{Sr}_{0.4} \mathrm{Co}_{0.2} \mathrm{Fe}_{0.8} \mathrm{O}_{3-\delta} \quad$ membranes, J. Membr. Sci. 447 (2013) $297-305$. https://doi.org/10.1016/j.memsci.2013.07.030

34 F. Schulze-Küppers, S. Baumann, F. Tietz, H.J.M. Bouwmeester, W.A. Meulenberg, Towards the fabrication of $\mathrm{La}_{0.98-\mathrm{x}} \mathrm{Sr}_{x} \mathrm{Co}_{0.2} \mathrm{Fe}_{0.8} \mathrm{O}_{3-\delta}$ perovskite-type oxygen transport membranes, J. Europ. Ceram. Soc. 34 (2014) 37413748. https://doi.org/10.1016/j.jeurceramsoc.2014.06.012 
35 N. H. Menzler, J. Malzbender, P. Schoderböck, R. Kauert, H. P. Buchkremer, Sequential Tape Casting of Anode-Supported Solid Oxide Fuel Cells, Fuel Cells 14 (2014) 96-106. https://doi.org/10.1002/fuce.201300153

36 P. Niehoff, F. Schulze-Küppers, S. Baumann, W.A. Meulenberg, O. Guillon, R. Vaßen, Fabrication of laboratory-scale planar oxygen separation membrane modules, Am. Ceram. Soc. Bull. 94 (2015) 28-31.

37 P. Niehoff, F. Schulze-Küppers, S. Baumann, R. Vaßen, H.-P. Buchkremer, W.A. Meulenberg, Manufacturing and performance of supported BSCF membranes for oxygen, in: W.M. Kriven, D. Zhu, K.I. Moon, T. Hwang, C. Lewinsohn, Y. Zhou (eds.) Developments in Strategic Materials and Computational Design V, Ceramic Engineering and Science Proceedings 35 (8) 325-335, Wiley, Hoboken, USA (2014).

38 S. Baumann, W.A. Meulenberg, H.P. Buchkremer, Manufacturing strategies for asymmetric ceramic membranes for efficient separation of oxygen from air, J. Europ. Ceram. Soc. 33 (2013) 1251-1261.

39 W. Schafbauer, F. Schulze-Küppers, S. Baumann, W.A. Meulenberg, N.H. Menzler, H.P. Buchkremer, D. Stöver, Tape Casting as a Multi-Purpose Shaping Technology for Different Applications in Energy Issues, Ma. Sci. Forum 706-709 (2012) 1035-1040.

40 L.E. Khoong, Y.M. Tan, Y.C. Lan, Overview on fabrication of three-dimensional structures in multi-layer ceramic substrate, J. Europ. Ceram. Soc. 30 (2010) 1973-1987.

41 H. Hellebrand, Tape Casting, in Processing of Ceramics, R.J. Brooks (Ed.), Wiley-VHC, Weinheim, Germany (1996). https://doi.org/10.1002/9783527603978.mst0192

42 M. L. Hallensleben, Polyvinyl Compounds, Others. In Ullmann's Encyclopedia of Industrial Chemistry, (Ed.). (2000). https://doi.org/10.1002/14356007.a21_743

43 F. Schulze-Küppers, S. Baumann, W.A. Meulenberg, D. Stöver, H.-P. Buchkremer, Manufacturing and performance of advanced supported $\mathrm{Ba}_{0.5} \mathrm{Sr}_{0.5} \mathrm{Co}_{0.8} \mathrm{Fe}_{0.2} \mathrm{O}_{3-\delta}$ (BSCF) oxygen transport membranes, J. Membr. Sci. 433 (2013) 121-125. https://doi.org/10.1016/j.memsci.2013.01.028

44 A. Mai, V.A.C. Haanappel, S. Uhlenbruck, F. Tietz, D. Stöver, Ferrite-based perovskites as cathode materials for anode-supported solid oxide fuel cells: Part I. Variation of composition, Solid State Ionics 176 (2005) 13411350 .

45 EN 1389:2003 Advanced technical ceramics. Ceramic composites. Physical properties. Determination of density and apparent porosity.

46 P. Niehoff, S. Baumann, F. Schulze-Küppers, R. Bradley, I. Shapiro, W.A. Meulenberg, P.J. Withers R. Vaßen, Oxygen transport through supported $\mathrm{Ba}_{0,5} \mathrm{Sr}_{0,5} \mathrm{Co}_{0,5} \mathrm{Fe}_{0,2} \mathrm{O}_{3-\delta}$ membranes, Sep. Purif. Technol., 121 (2014) 60-67. http://dx.doi.org/10.1016/j.seppur.2013.07.002

47 F. Schulze-Küppers, U.V. Unije, H. Blank, M. Balaguer, S. Baumann, O. Guillon, W.A. Meulenberg, Comparison of freeze-dried and tape-cast support microstructure on high-flux oxygen transport membrane performance, J. Membr. Sci. 564 (2018) 218-226. https://doi.org/10.1016/j.memsci.2018.07.028

48 M. Betz, F. Schulze-Küppers, S. Baumann, W.A. Meulenberg, D. Stöver, Supported oxygen transport membranes for Oxyfuel power plants, Adv. Sci. Technol. 72 (2010) 93-98

49 P. Lemes Rachadel, J. Motuzas, R.A.F. Machado, D. Hotza, J.C. Diniz da Costa, Influence of porous structures on O2 flux of BSCF asymmetric membranes, Separation and Purification Technology 175 (2017) 164-169. http://dx.doi.org/10.1016/j.seppur.2016.10.053

50 U. Unije, R. Mücke, P. Niehoff, S. Baumann, R. Vaßen, O. Guillon, Simulation of the effect of the porous support on flux through an asymmetric oxygen transport membrane, J. Membr. Sci. 524 (2017) 334-343. https://doi.org/10.1016/j.memsci.2016.10.037 